\title{
EXIT SURVEY KEPUASAN WISATAWAN TERHADAP PARIWISATA DI LABUAN BAJO
}

\author{
Apriana Marselina \\ Universitas Flores \\ Email: aprilradja82@gmail.com \\ Ernesta Leha \\ Universitas Flores \\ Email: leha_ernesta@yahoo.com \\ Maria Kristina Ota \\ Universitas Flores \\ Email: titynpaoh@gmail.com
}

\begin{abstract}
Tourism is one of the important sectors as a source of regional income. The satisfaction of each tourist depends on the facilities and services provided. The purpose of this survey is to measure the satisfaction of tourists who come and visit tourist destinations in Labuan Bajo. This survey activity also measures the success of the West Manggarai Regional Government, all stakeholders and the community in maintaining the sustainability of tourism in Labuan Bajo, as well as being able to answer user needs based on user experience. This survey was conducted using the exit survey method, by interviewing as many tourists as possible who had visited Labuan Bajo and were going out through the existing airport in Labuan Bajo. Based on the results of research on the level of visitor satisfaction with services and facilities in several tourist destinations in Labuan Bajo are between $55.28 \%$ to $76.45 \%$ of tourists satisfied with the existing facilities and services. This research contributes to the government of West Manggarai Regency in increasing the number of tourist visits and the development of facilities and services for tourists for each tourist destination in West Manggarai.
\end{abstract}

Keywords: Exit Survey, Tourist Satisfaction, Sustainable Tourism 


\section{Pendahuluan}

Labuan Bajo dikenal oleh dunia karena spesies biawak Komodo (varanus komodoensis) yang merupakan hewan langka yang berada di Taman Nasional Komodo dan Pulau Rinca. Sebagian besar wisatawan menganggap Labuan Bajo adalah Pulau Komodo padahal sesungguhnya Pulau Komodo adalah pulau tersendiri yang terpisah dari Labuan Bajo. Labuan Bajo adalah nama Ibu Kota Manggarai Barat dan merupakan pintu masuk wisatawan menuju ke Pulau Komodo dan pulau-pulau di sekitarnya, seperti Pulau Rinca, Pulau Kanawa, Pink Beach, Pulau Mata dan masih banyak lagi pulau lainnya yang berada di sekelilng Kota Labuan Bajo. Perannya sebagai entry point, inilah yang menjadikan Labuan Bajo ramai dikunjungi wisatawan, baik wisatawan domestik maupun wisatawan manca negara.

Labuan Bajo sebagai Ibu Kota Kabupaten Manggarai Barat secara administrasi berada di Kecamatan Komodo. Destinasi wisata yang berada di area Kota Labuan Bajo terdiri atas 7 tempat wisata. Pertama, Gua Batu Cermin yang terletak di Desa Waesambi. Gua Batu Cermin menyuguhkan pemandangan yang indah, perut bumi yang terbentuk secara alami pada ribuan tahun silam dengan cahaya yang terpancar melalui rongga dinding tebing di puncak gua pada jam 12 siang waktu setempat. Kedua, tempat wisata kuliner Kampung Ujung yang mulai dibuka pukul 17.00-00.00 waktu setempat.Wisata Kuliner Kampung Ujung menyajikan menu makan dengan berbagai varian menu. Ketiga, tempat Wisata Pantai Pede yang saat ini terlihat kurang menarik minat wisatawan karena tidak adanya akses masuk menuju pantai dan pemandangan sampah yang bertebaran sepanjang pantai. Keempat, Bukit Cinta yang berada tepat di belakang Bandar Udara Komodo Labuan Bajo. Untuk berwisata ke Bukit Cinta diperlukan waktu kurang lebih 15 menit dari kota Labuan Bajo menggunakan kendaraan bermotor. Dinamakan Bukit Cinta karena terlihat dari minat 
pengunjung yang merupakan pasangan muda-mudi yang datang untuk menikmati indahnya pemandangan di bukit tersebut.

Tempat wisata yang kelima adalah Bukit Amelia Sea. Jarak Bukit Amelia tidak terlalu jauh dari Bukit Cinta tetapi karena akses jalan menuju tempat tersebut yang harus memutar sehingga membuatnya terbilang jauh. Bukit ini dinamakan Amelia karena mengikuti nama sebuah Villa yang letaknya tidak jauh dari bukit tersebut. Tempat wisata ini terlihat lebih tinggi dibandingkan dengan Bukit Cinta. Dari ketinggian Bukit Amelia Sea pengunjung dapat melihat sisi timur dan sisi barat dari bagian utara Labuan Bajo. Letaknya yang berada di tengah-tengah labuan bajo sehingga membuat Bukit Amelia memiliki keistimewaan tersendiri. Bukit Amelia ini juga menjadi lokasi strategis untuk menikmati pemandangan sunset atau matahari terbenam disore hari. Akan tetapi untuk menikmati pemandangan yang ditawarkan melalui puncak Bukit Amelia ini pengunjung harus melakukan pendakian (trekking) agar bisa mencapai gugusan perbukitan Labuan Bajo bagian utara dari ketinggian.

Tempat wisata yang keenam yang tidak kalah menariknya dibandingkan bukit Amelia Sea adalah Bukit Silvia. Bukit Silvia hanya berjarak 200 meter dari Bukit Amelia. Dinamakan Bukit Silvia karena keberadaannya tidak jauh dari Resort Silvia yang terletak tepat di kaki bukit. Seperti di Bukit Amelia, di bukit ini pengunjung juga harus melakukan pendakian untuk bisa menikmati keindahan dari ketinggian. Tempat wisata yang ketujuh adalah Dermaga Putih yang terletak di Kampung Ujung yang juga merupakan tempat yang strategis untuk menunggu matahari terbenam. Dermaga ini dikelola oleh pihak swasta dan menjadi tempat berlabuh kapal-kapal wisata. Untuk dapat masuk ke Dermaga Putih, pengunjung dikenai tarif masuk tiket sebesar Rp.10.000,00 per orang. Tiket tersebut kemudian digunakan untuk ditukar kembali dengan minuman botol atau bisa juga digunakan untuk menyewa topi di area tersebut. 
Banyaknya destinasi wisata yang menarik di Labuan Bajo menjadikan wilayah ini penting untuk dikelola dan dirawat agar tempat-tempat wisata tersebut dapat memberikan dampak ekonomi bagi masyarakatnya (Murianto, 2014). Selain manfaat secara ekonomi, tata kelola destinasi dan ekosistem yang baik juga akan bermanfaat bagi keberlangsungan semua destinasi wisata tersebut. Keberlangsungan suatu destinasi wisata tidak terlepas dari banyaknya wisatawan yang datang berkunjung serta keterlibatan masyarakat dalam menjaga serta melestarikan tempat- tempat wisata tersebut (Modestus Ziku, 2015). Untuk meningkatkan kunjungan wisatawan ke tempattempat wisata, diperlukan peningkatan pelayanan terhadap pengunjung baik dari segi fasilitas sarana dan prasarana maupun kelayakan teknis (memberikan pelayanan yang menjaga keamanan wisatawan) serta kelayakan lingkungan (menyajikan lingkungan yang bersih bebas dari berbagai jenis sampah).

Dari penjelasan tersebut dapat disimpulkan bahwa peningkatan jumlah pengunjung pada suatu destinasi wisata sangat erat hubungannya dengan kepuasan pengunjung. Oleh karena itu tugas utama pihak Pemerintah Daerah Kabupaten Manggarai Barat maupun pihak swasta untuk terlibat langsung dalam upaya peningkatan sarana dan prasarana serta tata kelola pariwisata di Labuan Bajo. Hal ini penting karena keberlanjutan pariwisata berkaitan erat dengan kepuasan pengunjung dalam hal ini kepuasan wisatawan yang datang berkunjung ke destinasi tersebut. Kepuasan yang tinggi dari wisatawan memberikan dampak positif secara ekonomi pada masyarakat Labuan karena hal ini akan berkaitan dengan lama tinggal wisatawan, kemauan wisatawan membelanjakan uangnya serta intensitas kedatangan wisatawan yang juga akan semakin tinggi. Selain itu kepuasan wisatawan juga berkaitan dengan promosi yang baik untuk sebuah destinasi (Hill, Roche and Allen, 2007) sehingga dapat meningkatkan jumlah wisatawan yang berkunjung ke Labuan Bajo. 
Berdasarkan survey (Dinas Pariwisata, Kabupaten Manggarai barat, 2018) tentang kepuasan wisatawan yang datang berkunjung ke Labuan Bajo menggunakan metode Exit Survey. Berdasarkan hasil Exit Survey tersebut diketahui bahwa 54\% wisatawan menyatakan peran pemerintah serta masyarakat dalam menjaga serta melestarikam tempat wisata masih sangat terbatas. Bahkan 38\% mengatakan bahwa tidak ada peran pemerintah maupun masyarakat dalam menjaga serta melestarikan tempat wisata.

Sedangkan untuk kepuasan wisatawan, dari 138 responden ditemukan bahwa variasi dan keragaman mendapatkan nilai yang paling tinggi $(81 \%)$, disusul ketersediaan informasi dalam Bahasa Inggris (69\%), dan kualitas (66\%). Kebalikannya, untuk ketidakpuasan, adalah kebersihan yang nilainya paling buruk (38\%), fasilitas sanitasi $(20 \%)$, dan kepantasan harga (12\%). Dari penjelasan tersebut maka dapat disimpulkan bahwa diperlukan tindak lanjut yang lebih tepat sasaran oleh para pelaku wisata yang ada di Labuan Bajo khususnya Pemerintah Daerah Manggarai Barat beserta masyarakat yang memperoleh manfaat langsung dari keberadaan destinasi wisata tersebut.

Untuk mengetahui seberapa jauh keberhasilan yang telah dilakukan oleh Pemerintah Daerah dalam mewujudkan keberlangsungan destinasi wisata yang ada di Labuan Bajo, maka Tim MCSTO Uniflor bekerjasama dengan Dinas Pariwisata dan Sustour perlu melakukan survey lanjutan tentang kepuasan wisatawan yang datang berkunjung ke destinasi wisata yang ada di wilayah Labuan Bajo. Metode yang digunakan untuk mengukur kepuasan wisatawan masih sama yakni metode exit survey yang akan dilakukan kepada wisatawan manca negara dan wisatawan domestik. 


\section{Tujuan dan Manfaat Survey}

Tujuan survey ini adalah untuk mengukur kepuasan wisatawan yang datang dan berkunjung ke destinasi wisata di Labuan Bajo. Kegiatan survey ini sekaligus mengukur keberhasilan Pemerintah Daerah Manggarai Barat, seluruh stakeholder dan masyarakat dalam menjaga keberlanjutan pariwisata di Labuan Bajo. Sedangkan manfaat survey ini adalah untuk memperoleh data tentang kepuasan wiatawan yang akan dilaporkan kepada Kemenpar selaku penyandang dana dan Pemerintah Kabupaten Manggarai Barat sebagai bahan evaluasi dan menjadi salah satu landasan dalam merancang pembangunan pariwisata yang berkelanjutan di Labuan Bajo.

\section{Metodologi Penelitian}

\section{a) Lokasi dan Waktu Penelitian}

Lokasi penelitian ini adalah di Bandar Udara Internasional Komodo, Jl. Eltari, Kecamatan Komodo, Kabupaten Manggarai Barat, Nusa Tenggara Timur. Sedangkan waktu penelitian akan dilaksanakan dari tanggal 25 Agustus sampai 25 Oktober 2019.

\section{b) Populasi dan Sampel Penelitian}

Populasi yang digunakan dalan survey ini berdasarkan data kunjungan Wisatawan Manca negara dan Wisatawan Nusantara. Rata-rata kunjungan mulai dari bulan Januari s/d Juni 2019 sebanyak 11.275 pengunjung. Penentuan sampel menggunakan purposive sampling, dengan kriteria Responden dalam survey ini adalah Wisatawan Manca Negara dan Wisatawan Nusantara yang telah selesai melakukan kunjungan wisatanya di Labuan Bajo. 


\section{c) Metode Penentuan Sampel}

Penentuan sampel menggunakan rumus Slovin (Utama, 2016), maka banyaknya sampel dalam survey ini yang akan mewakili Populasi adalah sebagai berikut:

$$
\begin{gathered}
n=\frac{N}{1+\left(N x 0.1^{2}\right)} \\
n=\frac{11.275}{1+(11.275 \times 0.01)} \\
n=99,63 \text { Pengunjun } \\
n=100 \text { Pengunjun }
\end{gathered}
$$

Jadi berdasarkan perhitungan rumus slovin tersebut maka responden yang diambil dibulatkan menjadi 100 pengunjung.

\section{d) Metode Analisis Data}

Metode Survey yang digunakan adalah Exit Survey dengan cara menyebarkan kuesioner kepada responden yang berada di Bandar Udara Komodo Labuan Bajo yang telah menyelesaikan kunjungan wisatanya ke Labuan Bajo. Metode Analisis Data yang digunakan untuk mengukur tingkat kepuasan wisatawan adalah Indeks Kepuasan Pengunjung. Indeks Kepuasan Pengunjung (IKP) dihitung dengan rumus (Bhote,1996).

Secara rinci dapat dijabarkan rumusnya sebagai berikut : 
- Menghitung nilai rata-rata tingkat kinerja dan tingkat kepentingan

$$
x=\frac{\sum x}{n} \quad y=\frac{\sum x}{n}
$$

Keterangan:

$\mathrm{x}=$ nilai rata-rata tingkat kinerja

$y=$ nilai rata-rata tingkat kepentingan

- Indeks Kepuasan Pengunjung (IKP)

Indeks Kepuasan Pengunjung (IKP) dihitung dengan menggunakan rumus (Bhote, 1996).

$$
\mathrm{IKP}=\frac{T}{5 x Y} x 100 \%
$$

Keterangan:

$\mathrm{T}=$ skor total perkalian rata-rata $\mathrm{X}$ dan rata-rata $\mathrm{Y}$

$\mathrm{Y}=$ skor total rata-rata kepentingan $(\mathrm{Y})$

$5=$ nilai maksimum pada skala pengukuran

Kriteria Indeks Kepuasan Pengunjung mengacu pada Kriteria Interpretasi Skor yang di sampaikan oleh Ridwan (2009).

Kriteria Interpretasi Skor

Angka 0\% - 20\% = sangat tidak puas; Angka 21\% - 40\% = tidak puas Angka $41 \%-60 \%=$ cukup puas; Angka $61 \%-80 \%=$ puas; Angka 81\% $100 \%=$ sangat puas 


\section{Hasil Analisis Data Kepuasan Wisatawan di Labuan Bajo}

Salah satu kegiatan yang dilakukan sebagai bentuk studi pendahuluan dalam kaitan dengan tugas MCSTO Uniflor di Labuan Bajo adalah melakukan survey kepuasan wisatawan. Survey ini dilakukan dengan metode exit survey, yakni mewawancarai sebanyak mungkin wisatawan yang telah mengunjungi Labuan Bajo dan akan keluar (exit) melalui Bandara yang ada di Labuan Bajo. Dalam kegiatan survey kali ini, Tim kami berhasil mewawancarai 383 responden yang merupakan wisatawan manca negara dan wisatawan domestik. Kegiatannya survey ini dilakukan pada bulan Agustus s/d September 2019, dengan lokasi survey di Bandar Udara Komodo Labun Bajo. Alat analisis yang digunakan adalah SSPS dan TSI (Tourist Satisfaction Index) yang bertujuan untuk menganalisis Tingkat Kepuasan Wisatawan di Labuan Bajo .

\section{A. Identitas Wisatawan}

\section{Asal Wisatawan}

Wisatawan yang berkunjung ke Labuan Bajo berasal dari berbagai negara. Dari 383 responden, sebanyak $23 \%$ berasal dari Indonesia atau merupakan wisatawan domestik, sedangkan $77 \%$ merupakan wisatawan manca negara yang berasal dari berbagai negara. Dalam survey ini wisatawan manca negara terbanyak berasal dari negara Spanyol 20\%,disusul oleh negara Malaysia 17\%, sedangkan selebihnya berasal dari berbagai negara lain seperti yang tertera pada Gambar 2.1. 


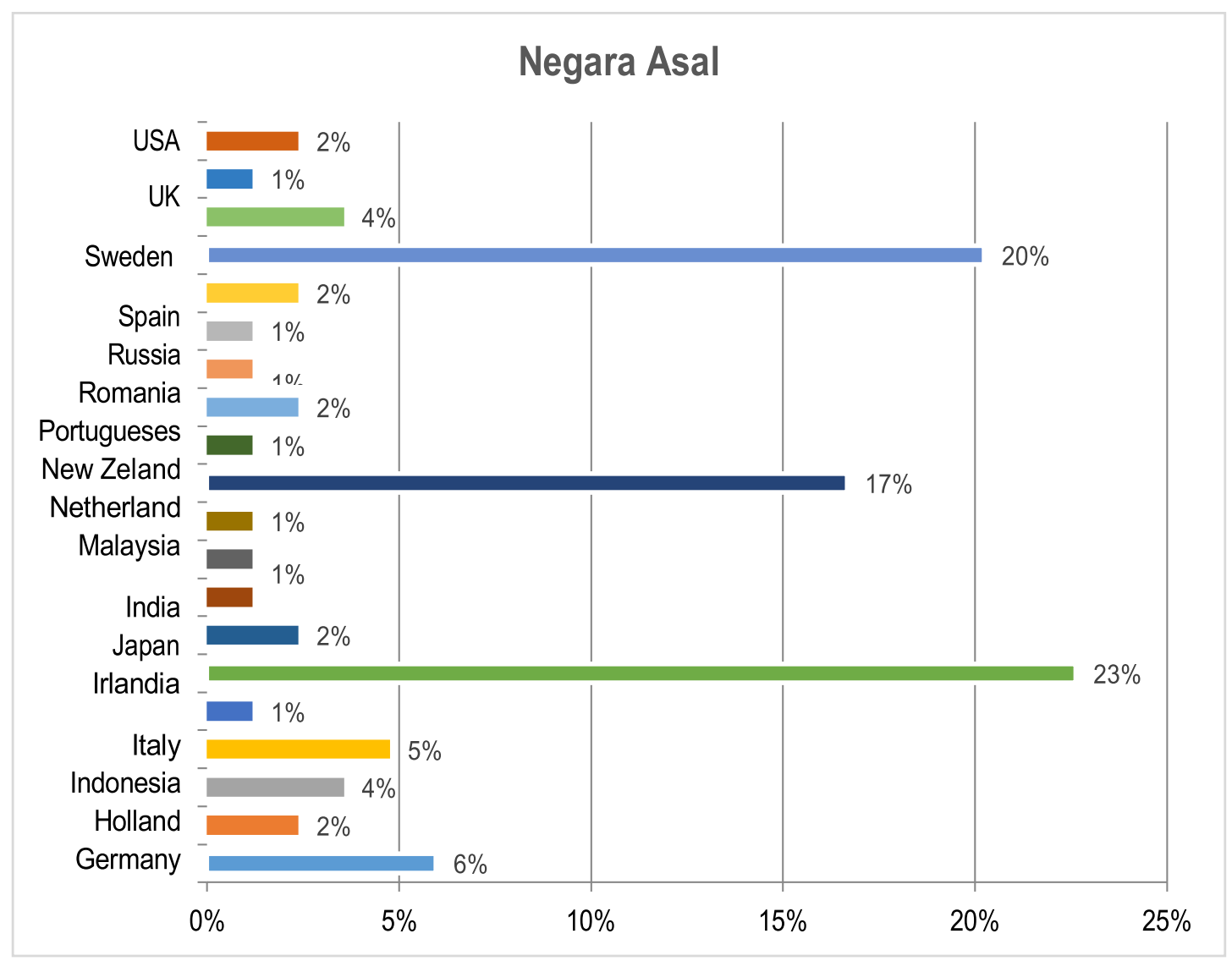

Gambar 1. Negara Asal Wisawatan

\section{Usia Responden}

Usia wisatawan yang berkunjung ke Labuan Bajo cukup beragam dengan persentase tertinggi pada range usia 23-27 tahun sebanyak 25\% dan range usia 28 - 32 tahun sebanyak $17 \%$. Sedangkan jumlah wisatawan dengan range di atas $37-47$ tahun adalah yang paling banyak, jika ditotal bisa mencapai 37\%. Yang menarik dari hasil exit survey kali ini adalah wisatawan yang datang berkunjung ke Labuan Bajo berasal dari berbagai tingkat usia. Baik dari usia di bawah 17 tahun sampai usia di atas 62 tahun. 


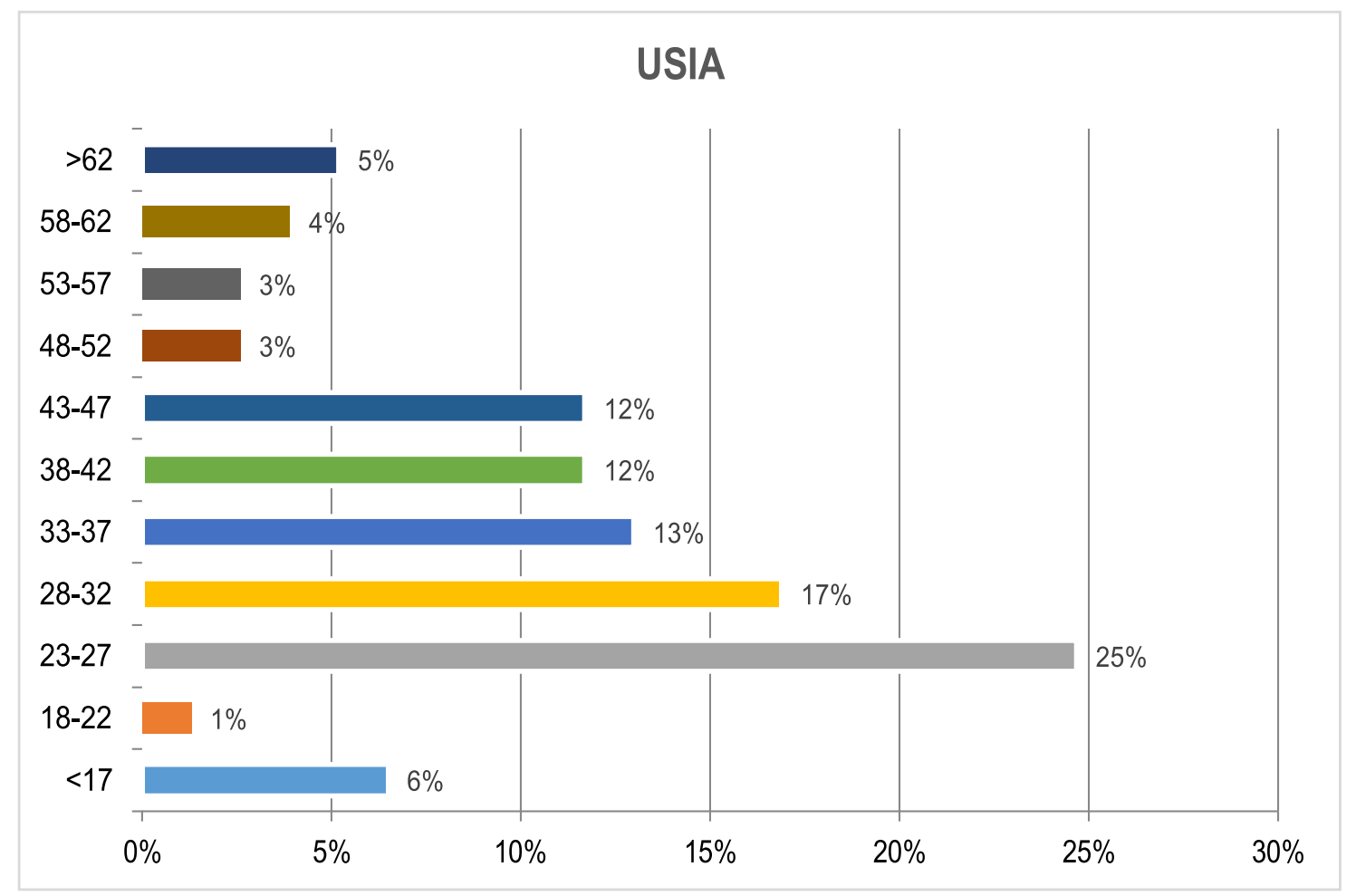

Gambar 2. Usia Wisatawan

\section{Pendidikan Responden}

Rata-rata tingkat pendidikan wisatawan yang paling tinggi adalah sarjana sebanyak 44\% diikuti oleh Magister (S2) 22\%, Diploma (D3) dan SLTA 13\%, serta yang paling sedikit adalah responden dengan tingkat pendidikan Doktor (S3). 


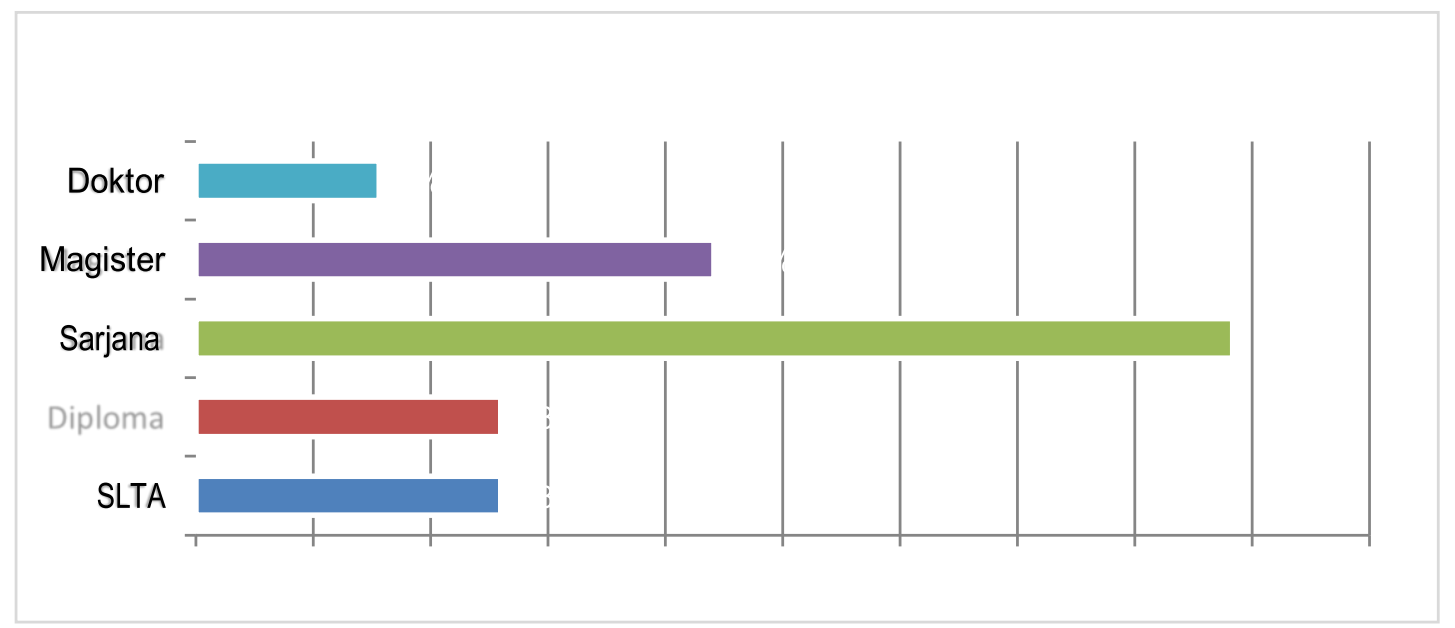

Gambar 3. Tingkat Pendidikan Wisatawan

\section{Jenis Kelamin}

Wisatawan yang menjadi responden paling banyak adalah laki-laki sebanyak 56\% dan perempuan sebanyak $44 \%$.

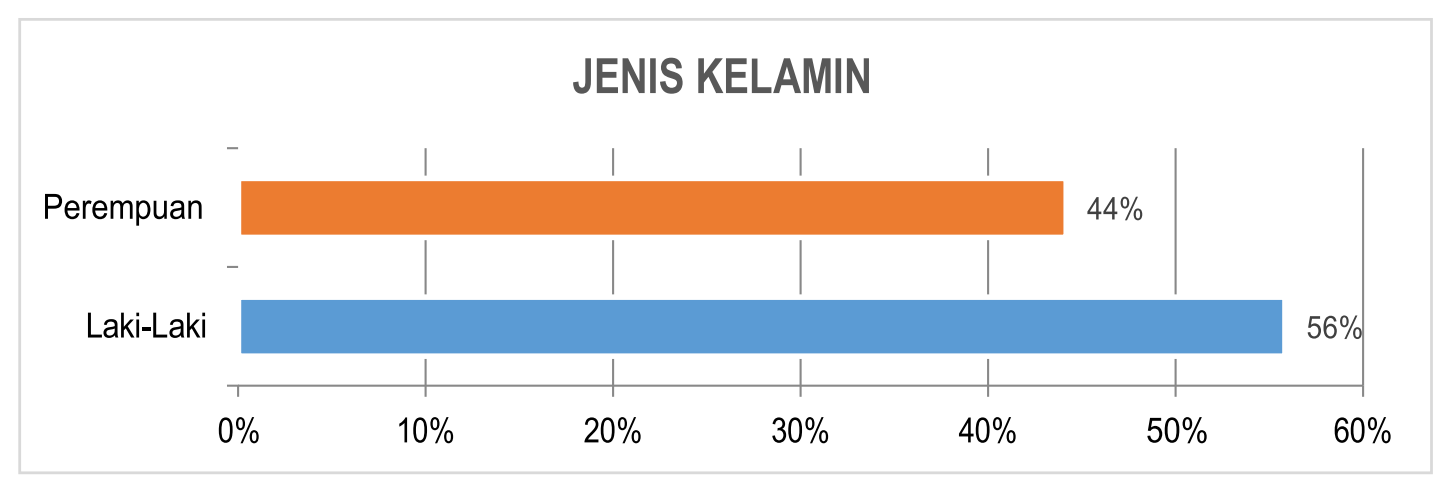

Gambar 4. Jenis Kelamin Responden

\section{Profesi Responden}

Profesi responden terbanyak adalah Wiraswasta (33\%), kemudian yang berprofesi sebagai Pegawai Swasta sebanyak 28\%, Pegawai Negeri 20\%, Pelajar 9\%, Pengangguran 7\%, Pensiunan 3\% dan Survey Pemetaan 1\%. Hal ini menunjukkan bahwa kuesioner disebarkan secara merata ke setiap wisatawan yang datang berkunjung ke Labuan Bajo. 400 JUMPA Volume 6, Nomor 2, Januari 2020 


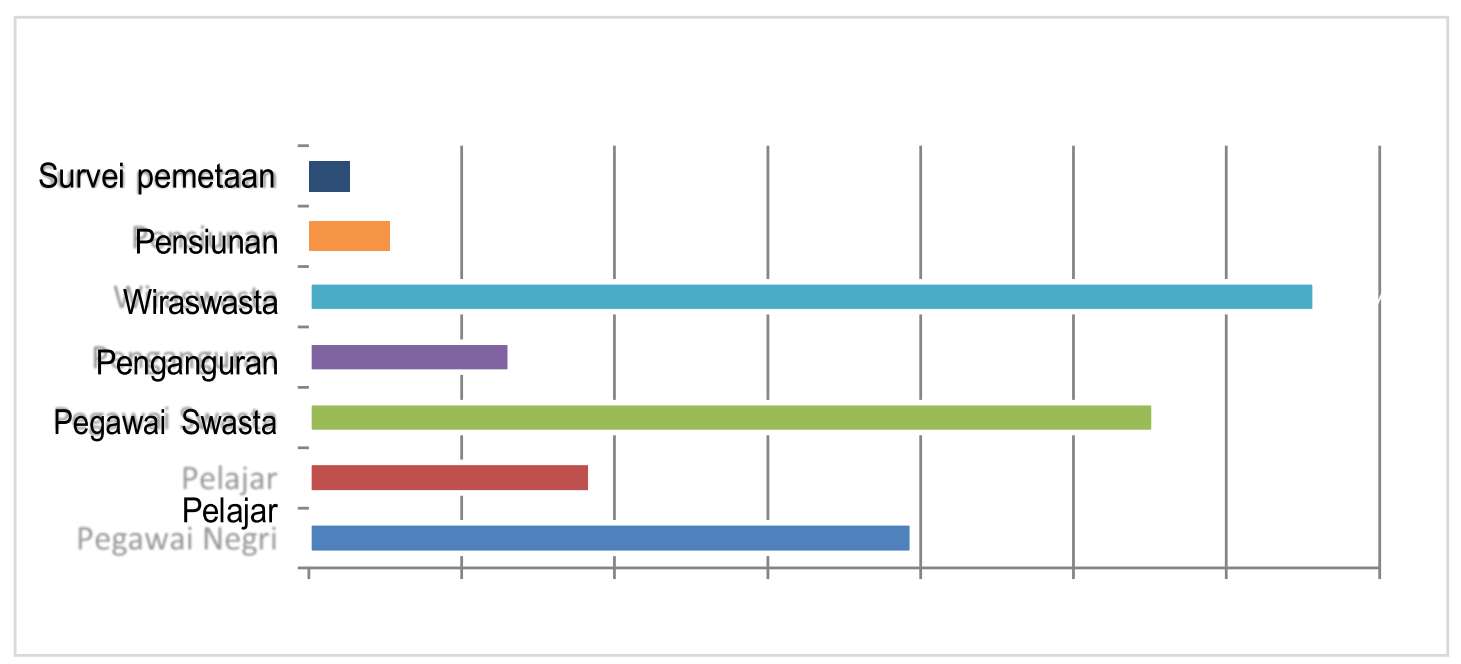

Gambar 5. Profesi Responden

\section{B. Proses Membuat Keputusan Kunjungan}

\section{Sumber Perolehan Informasi}

Sumber infomasi yang digunakan oleh wisatawan cukup beragam. Berdasarkan hasil analisis exit survey diketahui bahwa sumber informasi terbanyak yang membuat wisatawan ingin berkunjung ke Labuan Bajo adalah teman/anggota keluarga dengan persentase sebAnyak 29\%. Sumber informasi dari media sosial sebanyak 20\%, kemudian Website sebasnyak 18\%, forum Perjalanan 15\%, Buku Panduan Perjalanan $6 \%$, Offline/Online travel writing (majalah, surat kabar) 5\%, serta agen perjalanan. Dari hasil temuan ini dapat disimpulkan bahwa tingkat promosi yang dilakukan para stakeholder di Labuan Bajo belum berjalan maksimal karena wisatawan memperoleh informasi tentang Labuan Bajo lebih banyak melalui teman/anggota keluarga. Oleh karena itu diperlukan upaya peningkatan promosi tentang Labuan Bajo melalui website dan media online lainnya. 


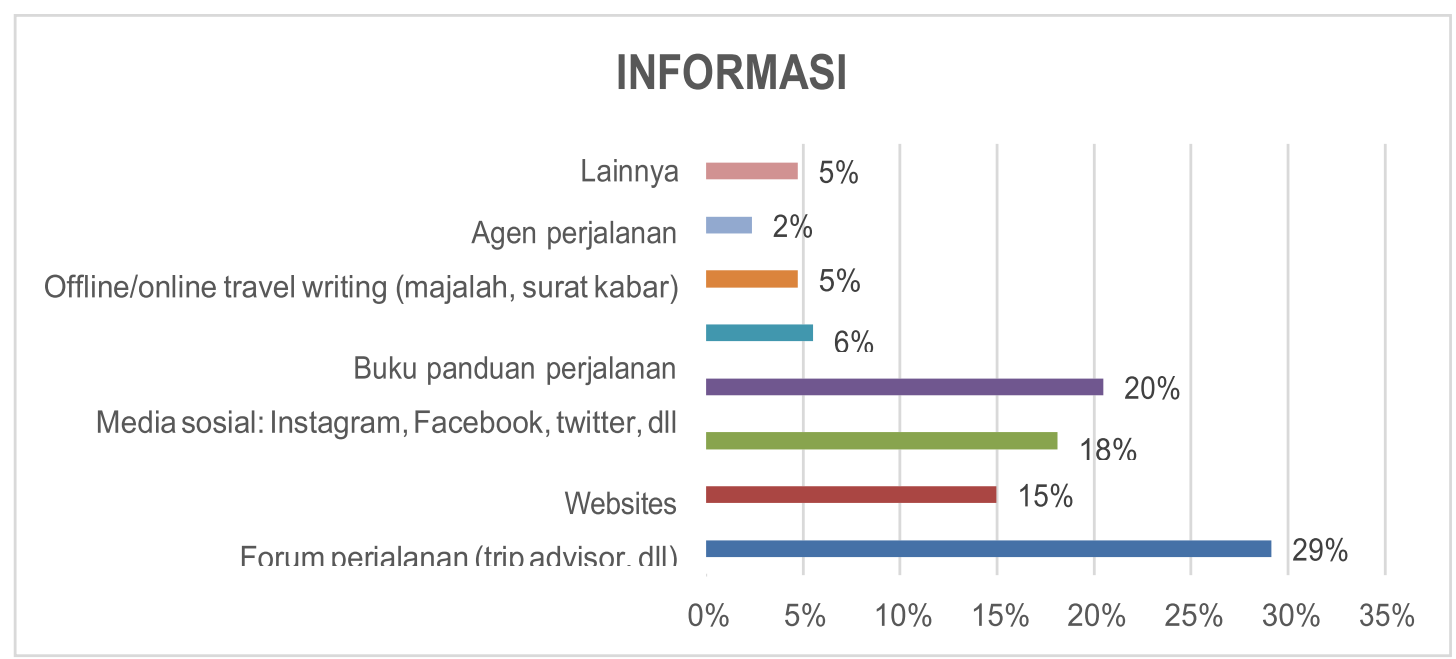

Gambar 6. Sumber Informasi Tentang Labuan Bajo

\section{Atraksi yang dilakukan di Labuan Bajo}

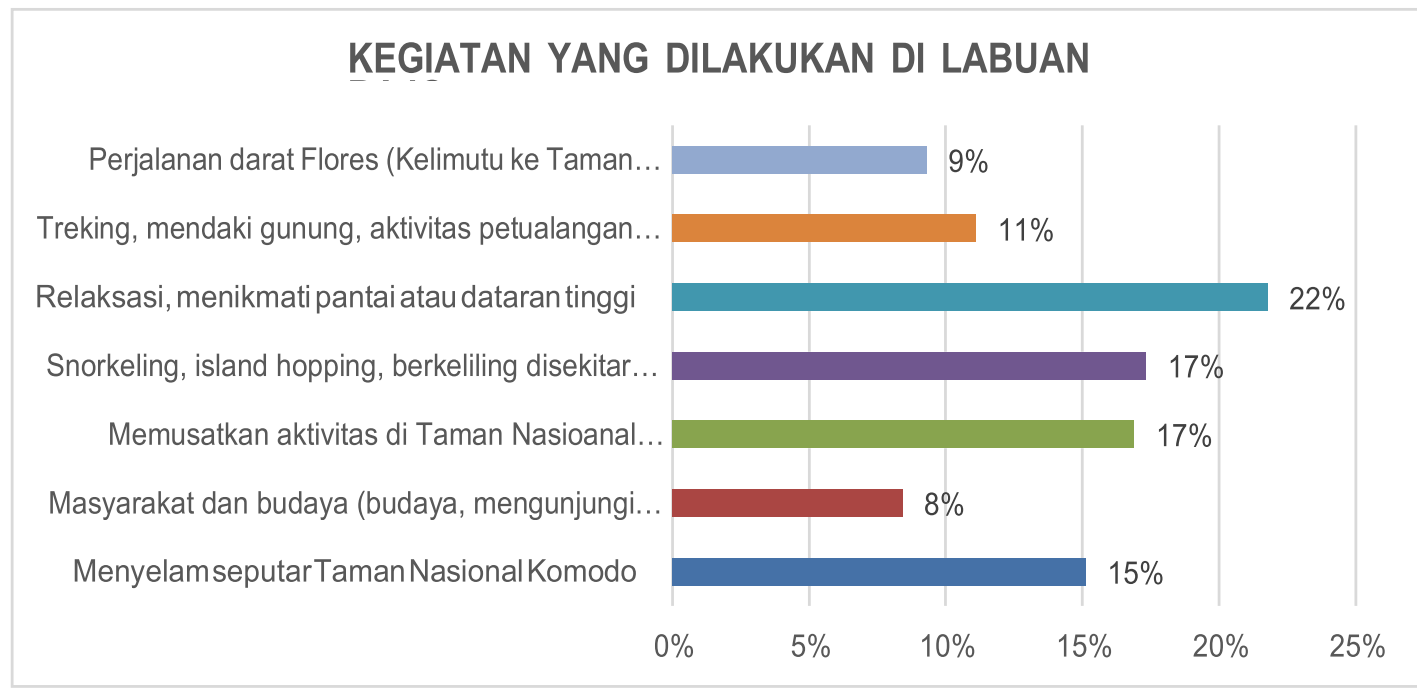

Gambar 7. Kegiatan Yang Dilakukan Pengunjung di Labuan Bajo

Kebanyakan wisatawan yang datang berkunjung ke Labuan Bajo melakukan kegiatan rekreasi, menikmati pantai dan dataran tinggi, hal ini di tunjukkan dengan grafik pada angka 22\%. Kegiatan lain seperti memusatkan aktivitas di Taman Nasional Komodo, 402 JUMPA Volume 6, Nomor 2, Januari 2020 
snorkeling, island hopping dan berkeliling di sekitar taman Nasional Komodo merupakan pilihan kedua terbanyak dari sejumlah kegiatan yang dilakukan yaitu sebanyak $17 \%$. Kegiatan selanjutnya adalah untuk menyelam di seputar Taman Nasional Komodo 15\%, trekking 11\%, perjalan darat Flores 9\% dan yang terakhir untuk menyaksikan pentas budaya yang dilakukan oleh masyarakat sebanyak $8 \%$. Hal ini menunjukkan bahwa citra Labuan Bajo di mata dunia adalah memiliki pemandangan pantai yang indah serta dataran tinggi yang dapat dipakai untuk bersantai. Oleh karena itu diperlukan penataan yang lebih baik lagi terkait pantai yang ada di sekitar Labuan Bajo agar dapat dimanfaatkan secara maksimal oleh para wisatawan.

\section{Lama Tinggal Wisatawan}

\section{Jumlah Hari Lama Tinggal Wisatawan di Labuan Bajo}

Rata-rata lama tinggal wisatawan di Labuan Bajo adalah 5,13 hari dan persentase lama tinggal wisatawan yang paling banyak adalah 3 hari sebanyak 22\%. Lama tinggal 5 hari sebanyak $21 \%$. Sedangkan lama tinggal 6 hari sebanyak $16 \%$ dan 7 hari sebanyak $14 \%$. Hal ini menunjukkan bahwa tidak cukup 1 hari untuk menikmati keindahan alam yang ada di Labuan Bajo ini. Bahkan ada 7\% wisatawan yang mau menghabiskan waktu lebih dari seminggu di Labuan Bajo. Situasi ini menunjukkan bahwa banyak hal yang masih harus dilakukan agar menarik wisatawan untuk dapat tinggal lebih lama lagi di Labuan Bajo ini. 


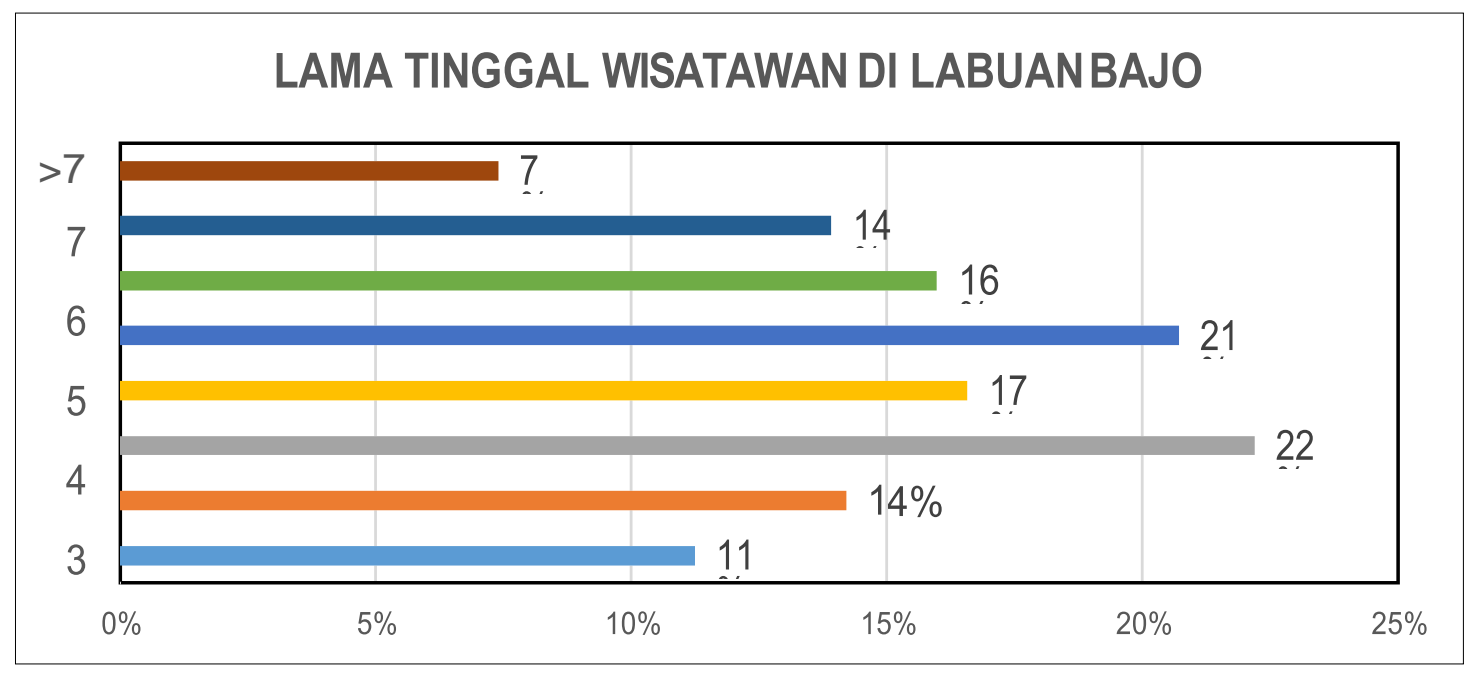

Gambar 8. Lama Tinggal Wisatawan di Labuan Bajo

\section{Jumlah Wisatawan yang Pertama kali berkunjung ke Labuan Bajo}

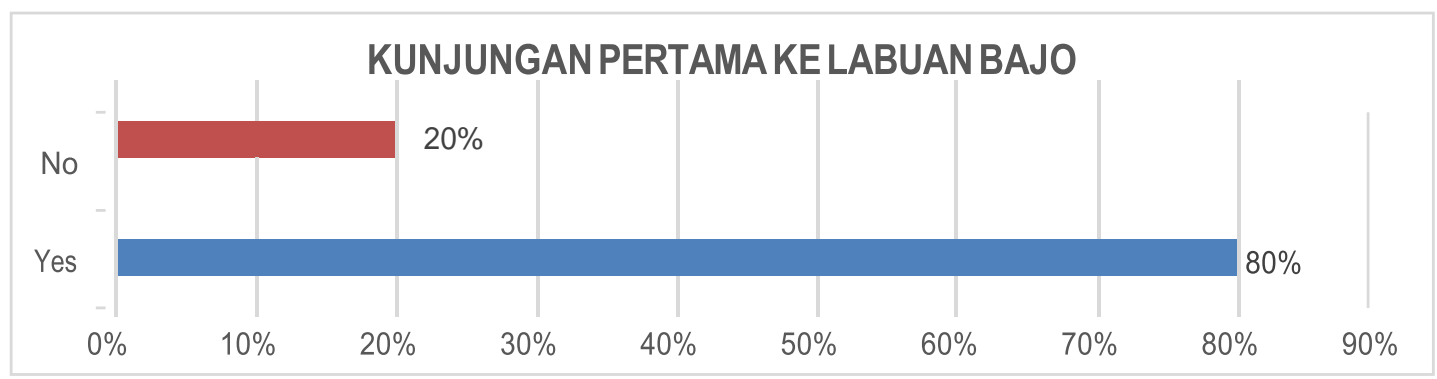

Gambar 9. Kunjungan Pertama ke Labuan Bajo

Kebanyakan wisatawan yang datang ke Labuan Bajo menyatakan bahwa kedatangannya ke Labuan Bajo merupakan kunjungan yang pertama. Hal ini dibuktikan dengan grafik dimana 80\% merupakan kunjungan pertama kali sedangkan 20\% merupakan kunjungan yang kedua bahkan yang ketiga kalinya. Dari kondisi ini dapat disimpulkan dua hal yakni (1) Labuan Bajo menarik minat wisatawan yang belum pernah berkunjung ke Labuan Bajo dan (2) dari sekian banyak wisatawan yang sudah pernah datang, hanya sedikit sekali (20\%) yang ingin kembali lagi untuk kedua 
kali atau ketiga kalinya. Ini berarti, Labuan Bajo perlu melakukan evaluasi tentang semua hal yang perlu dibenahi termasuk meningkatkan atraksi wisata alternatif untuk menarik wisatawan datang berkali-kali ke Labuan Bajo.

\section{Jumlah Wisatawan yang lebih dari satu kali berkunjung ke Labuan Bajo}

Dari $20 \%$ jumlah wisatawan yang datang untuk kesekian kalinya, terdapat $98 \%$ yang menyatakan bahwa kedatangannya saat itu merupakan kunjungan yang kedua, sedangkan 2\% merupakan wisatawan yang melakukan kunjungan yang ketiga kalinya. Hal ini menunjukkan bahwa daya tarik destinasi wisata yang ada di Labuan Bajo sangat besar karena mampu mengundang wisatawan untuk datang lagi ke Labuan Bajo. Daya tarik ini yang harus dijaga dengan meningkatkan kepuasan wisatawan karena berdasarkan teori yang ada, orang yang puas akan sesuatu yang didapatkan akan cenderung melakukan hal yang sama untuk kedua kali bahkan kesekian kali berikutnya (Kotler, 2009).

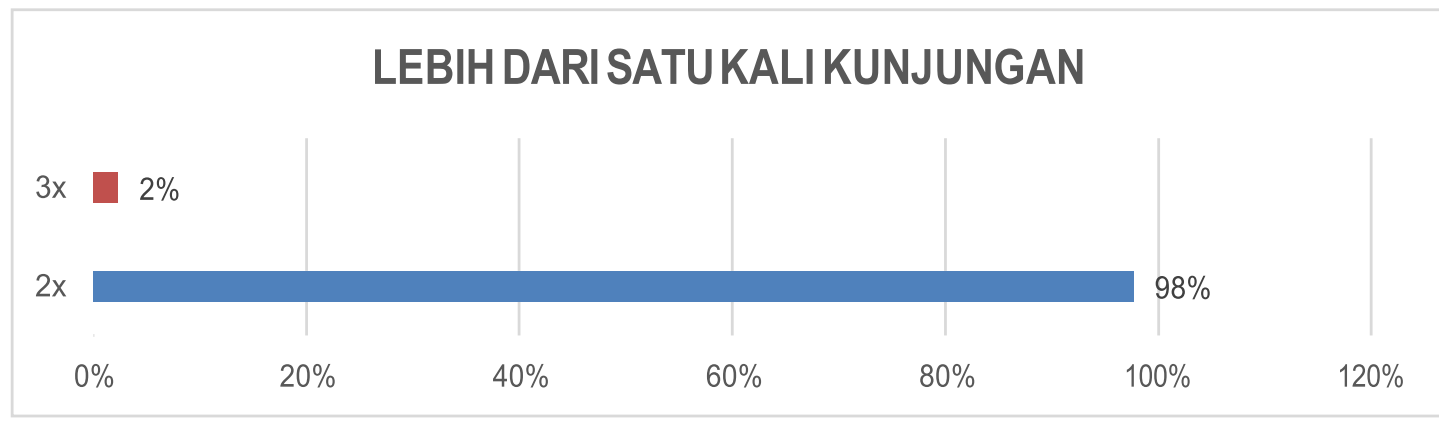

Gambar 10. Jumlah Wisatawan Yang Berkunjung Lebih dari Satu Kali

\section{Kesesuaian Antara Rencana Kunjungan Dengan Lama Kunjungan}

Dari data yang dikumpulkan diperoleh informasi bahwa kebanyakan wisatawan yang melakukan kunjungan ke Labuan Bajo menyelesaikan masa kunjungannya sesuai dengan yang direncanakan. Hal ini ditunjukkan dengan grafik sebanyak 86\% 
wisatawan menyelesaikan kunjungannya sesuai dengan rencana yang telah dibuat, sedangkan hanya $8 \%$ wisatawan menyatakan bahwa menyelesaikan kunjungnya lebih singkat dari yang direncanakan. Sedangkan 6\% dari wisatawan menyatakan menyelesaikan kunjungannya lebih lama dari yang di rencanakan. Hal ini menunjukkan bahwa daya tarik Labuan Bajo belum mampu "menahan" wisatawan untuk dapat tinggal lebih lama lagi di Labuan Bajo. Dengan demikian ini merupakan tugas yang harus dilakukan oleh Pemerintah dan MCSTO sebagai mitra untuk menata dan membuat agar daya tarik Labuan Bajo semakin meningkat. Karena alasan keberlanjutan adalah jika sesuatu dapat dipertahankan dan dikembangkan, jika tidak akan punah dan mati.

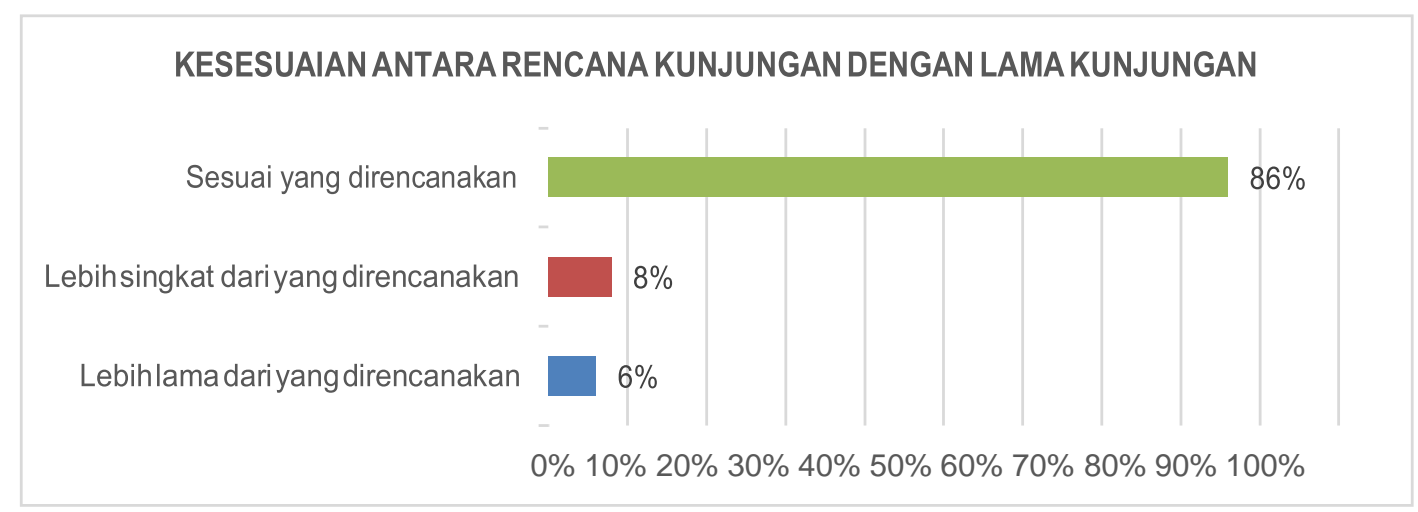

Gambar 11. Kesesuaian Renncana Kunjungan dengan Lama Kunjungan

\section{Pemilihan Labuan Bajo Merupakan Destinasi Utama Liburan}

Secara umum wisatawan menyatakan bahwa Labuan Bajo bukan merupakan destinasi utama yang menjadi tujuan liburan yang direncanakan (53\%). Sedangkan $47 \%$ wisatawan yang menyatakan bahwa Labuan Bajo merupakan destinasi utama tujuan liburan yang direncanakan. Hal ini menunjukkan bahwa masih banyak tempat di 406 JUMPA Volume 6, Nomor 2, Januari 2020 
Indonesia yang menjadi target utama tujuan wisata para wisatawan selain Labuan Bajo. Atau dengan kata lain, Labuan Bajo hanya merupakan tempat persinggahan dalam perjalanan mereka menuju tempat destinasi utama liburan.

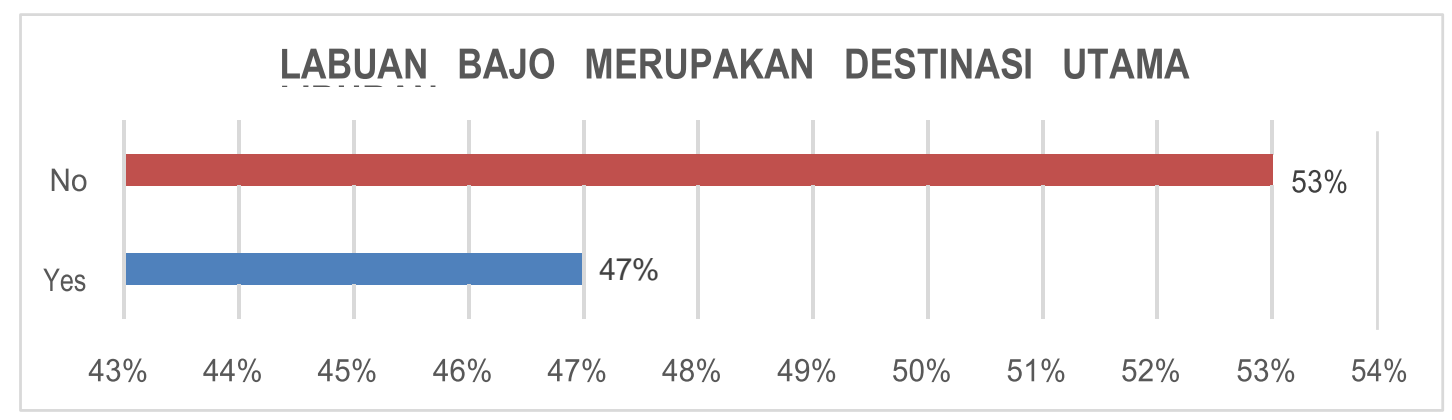

Gambar 12. Pemilihan Labuan Bajo Sebagai Destinasi Utama Liburan

\section{E. Organisasi Perjalanan Dan Harga}

\section{Organisasi Perjalanan ke Labuan Bajo}

Berdasarkan hasil survey yang dilakukan, sebanyak 68\% wisatawan yang datang berkunjung ke Labuan Bajo mengatur sendiri perjalannnya sedangkan yang lainnya melakukan perjalanan dengan memanfaatkan tour operator dan berasal dari Labuan Bajo

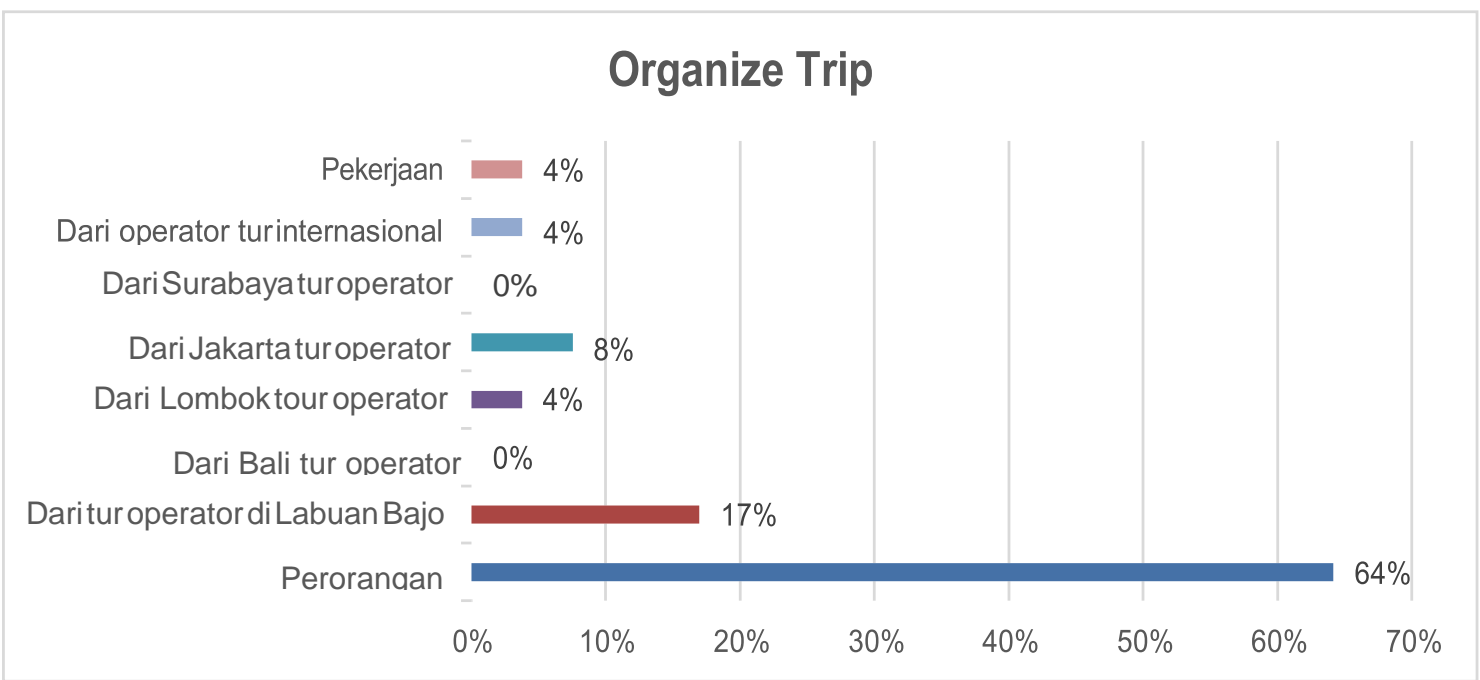


Gambar 13. Organisasi Perjalanan Yang Digunakan Wisatawan

\section{Total Biaya Yang Dikeluarkan Wisatawan Selama di Labuan Bajo}

Kisaran biaya yang paling bayak dikeluarkan oleh wisatawan adalah antara US\$10012000 yaitu sebanyak 27\%. Ini setara dengan Rp.15.000.000,- s/d Rp. 30.000.000,-. Hal ini menunjukkan bahwa pendapatan dari sektor pariwisata sangat besar terutama jika lama tinggal wisatawan bisa ditingkatkan melalui pembenahan iklim pariwisata di Labuan Bajo.

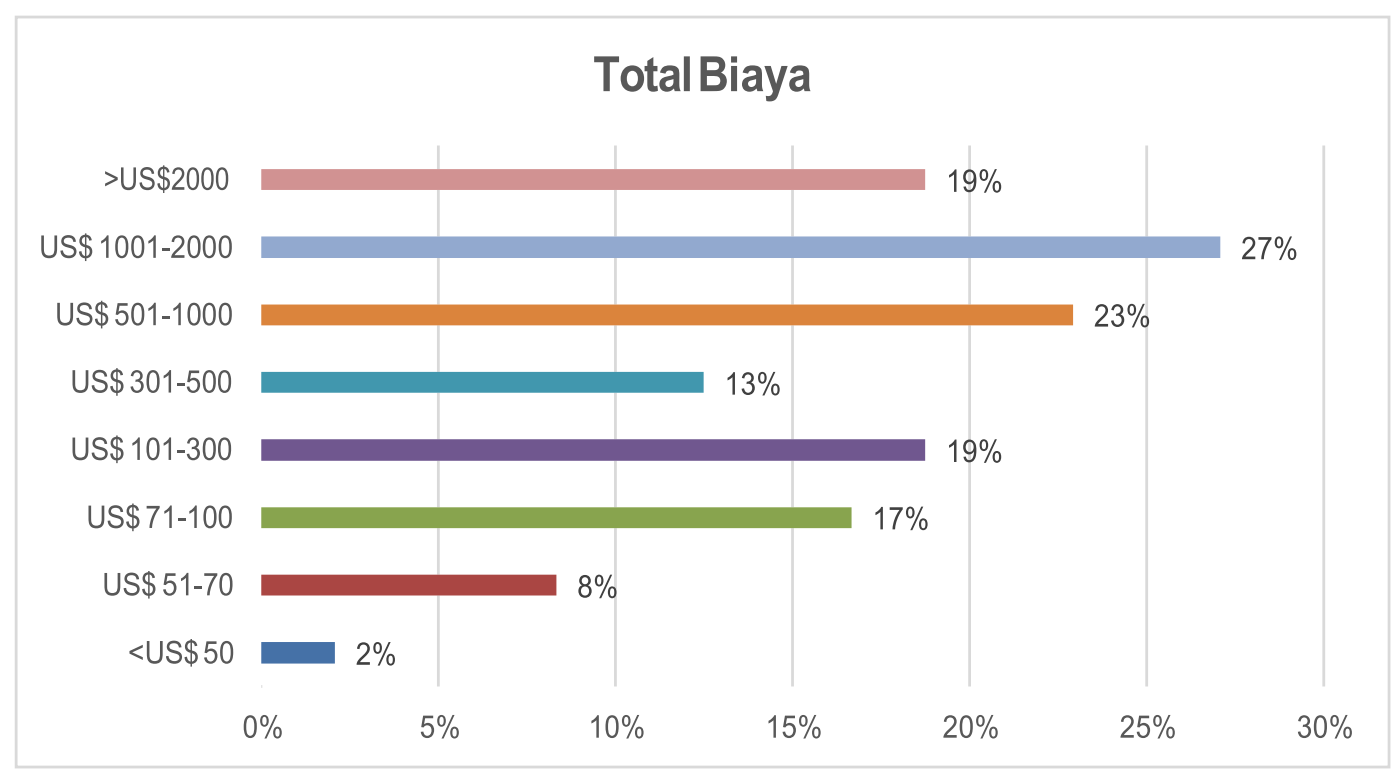

Gambar 14. Total Biaya Yang Dikeluarkan Wisatawan Selama di Labuan Bajo

\section{Jumlah Wisatawan yang Membeli Souvenir}

Berdasarkan hasil survey diketahui bahwa jumlah wisatawan yang menyatakan membeli souvenir sebanyak $51 \%$ dan yang tidak membeli sebanyak $49 \%$. Secara faktual ketersediaan souvenir yang khas Labuan Bajo memang terbatas. Yang ada selama ini hanya souvenir dalam bentuk kain tenun, topi, tas dan makanan lokal tetapi dalam 
jumlah yang terbatas. Hal ini menunjukkan bahwa masih banyak hal yang harus dibenahi terkait ketersediaan souvenir di Labuan Bajo.

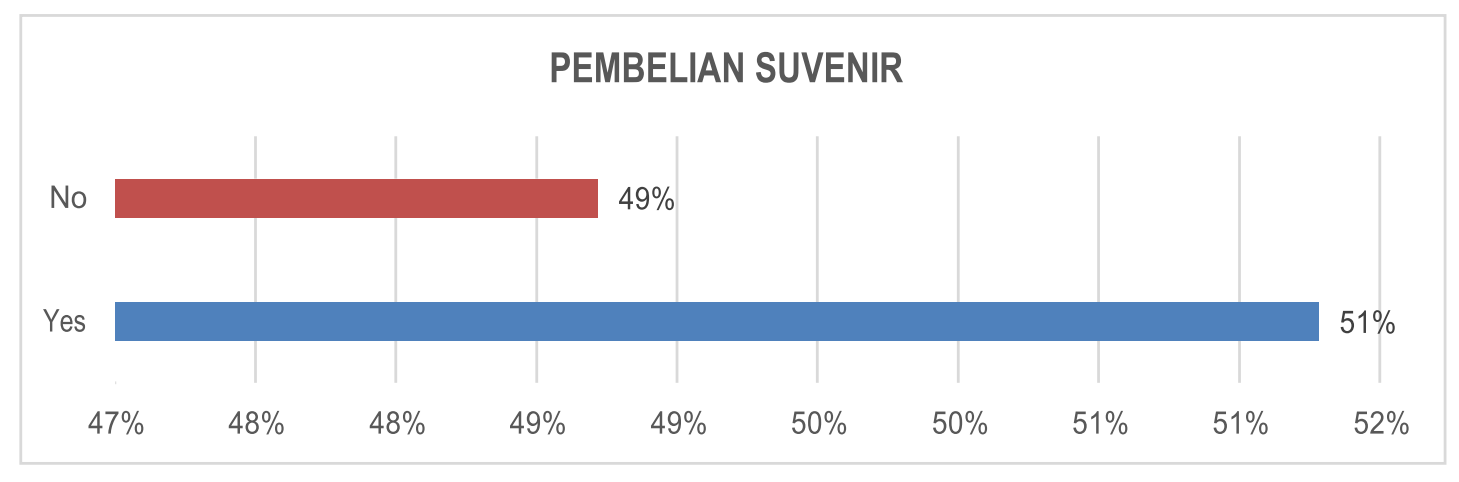

Gambar 15. Pembelian Souvenir

\section{Jenis Suvenir Yang Diminati}

Jenis souvenir yang paling diminati oleh wisatawan adalah produk pertanian (kopi, kacang mente dll) sebanyak 35\%, yang kedua adalah tenun ikat 29\%. Selanjutnya makanan lokal (kompyang, camilan, makanan laut, ikan asin/cumi, sambal, dll) 14\%, pakaian (kaos oblong, topi, tas jinjing, dll) 12\%, selebihnya aksesoris kecantikan 6\%, kerajinan kayu (patung komodo, gantungan kunci dll) 4\% dan souvenir dari bahan daur ulang hanya $1 \%$. Besarnya daya beli wisatawan terhadap souvenir lokal seharusnya menjadi tantangan bagi Pemerintah Daerah dan Pegiat Pariwisata untuk meningkatkan kreativitas dalam menambah ragam souvenir yang berkualitas di Labuan Bajo. 


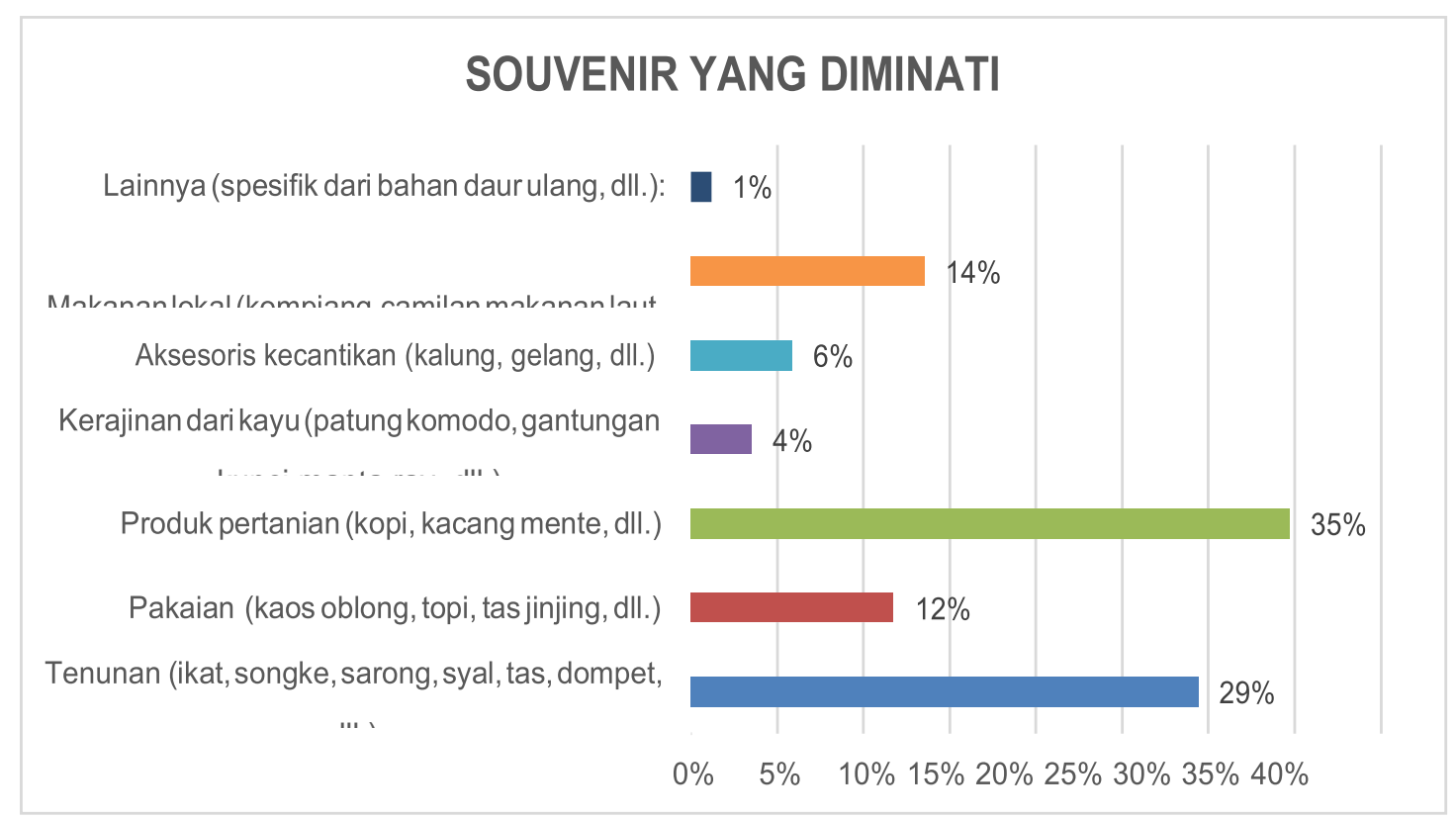

Gambar 16. Jenis Souvenir Yang Diminati

\section{Total Biaya Pembelian Suvenir}

Dari $51 \%$ wisatawan yang menyatakan membeli souvenir, 55\% dari jumlah tersebut mengeluarkan uang dengan nominal di atas US\$ 51 s/d 500, atau lebih besar dari Rp.750.000 sampai dengan Rp.7.500.000. Sedangkan sebanyak 45\% wisatawan mengeluarkan biaya pembelian souvenir kurang dari US\$ 50 atau kurang dari Rp.750.000. Hal ini menunjukkan bahwa souvenir merupakan daya tarik tersendiri bagi wisatawan ketika mengunjungi sebuah destinasi wisata. 


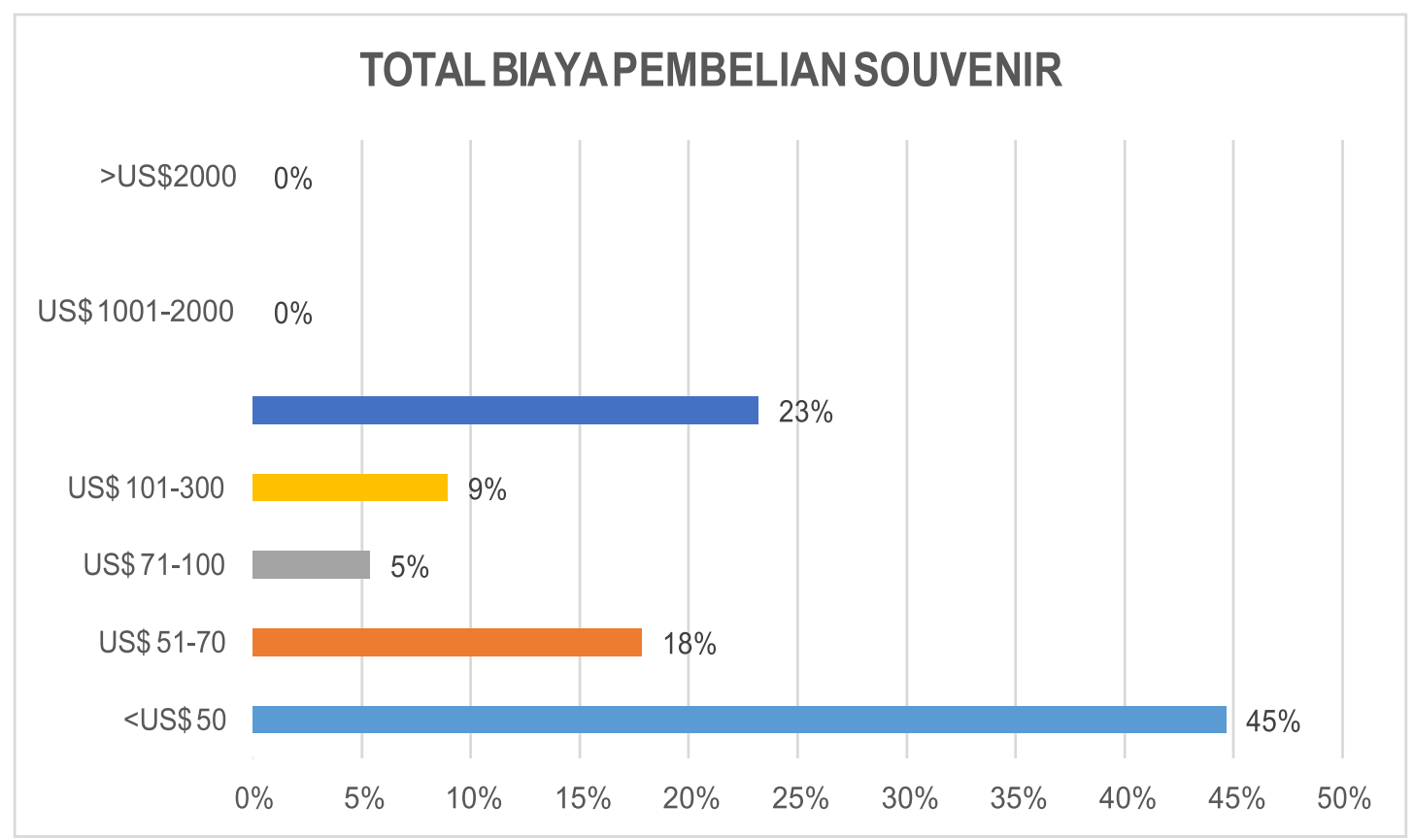

Gambar 17. Total Biaya Pembelian Souvenir

\section{Tempat Pembelian Souvenir}

Dari hasil survey diketahui bahwa $40 \%$ wisatawan membeli souvenir melalui toko souvenir, $27 \%$ dari pedagang kaki lima, 20\% dari toko-toko di sekitar tempat wisata, $7 \%$ membeli langsung dari pembuat souvenir dan hotel. Sedangkan di Bandara dan Pasar Tradisional tidak terjadi transaksi pembelian souvenir yang dilakukan oleh wisatawan. 


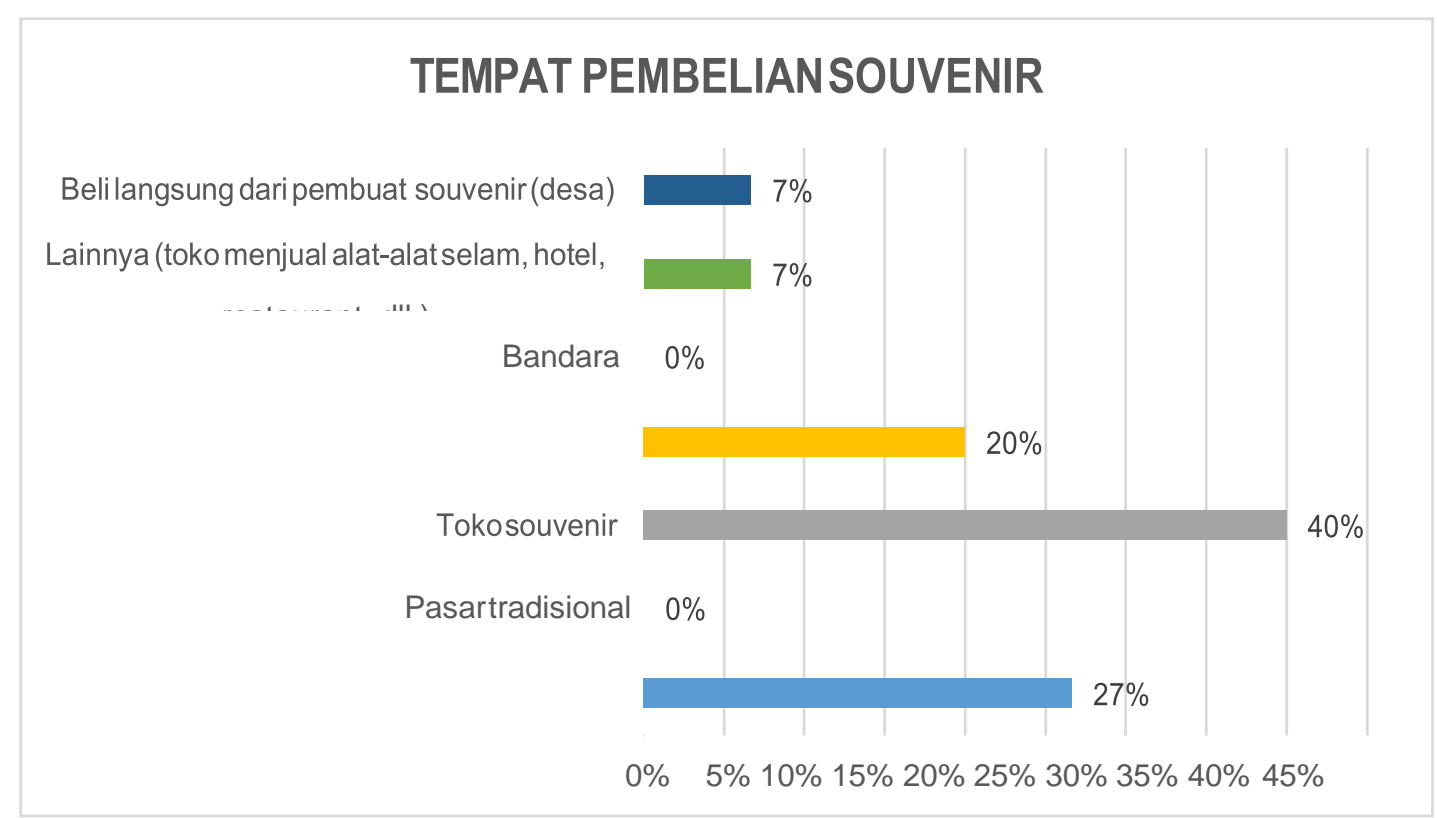

Gambar 18. Tempat Wisatawan Membeli Souvenir

\section{F. Persepsi Kesadaran Wisatawan Terhadap Pariwisata Berkelanjutan Di Taman Nasional Komodo}

\section{Jumlah Informasi yang diperoleh}

Sebanyak $42 \%$ wisatawan menyatakan banyak mendapatkan informasi tentang keberlanjutan suatu destinasi wisata sedangkan 29\% mengatakan memperoleh informasi yang sedikit tentang keberlanjutan dan $29 \%$ wisatawan mengatakan sama sekali tidak pernah memperoleh informasi tentang pariwisata keberlanjutan. Hal ini menunjukkan bahwa hanya $42 \%$ wisatawan yang paham tentang pentingnya keberlanjutan sebuah destinasi.

412 JUMPA Volume 6, Nomor 2, Januari 2020 


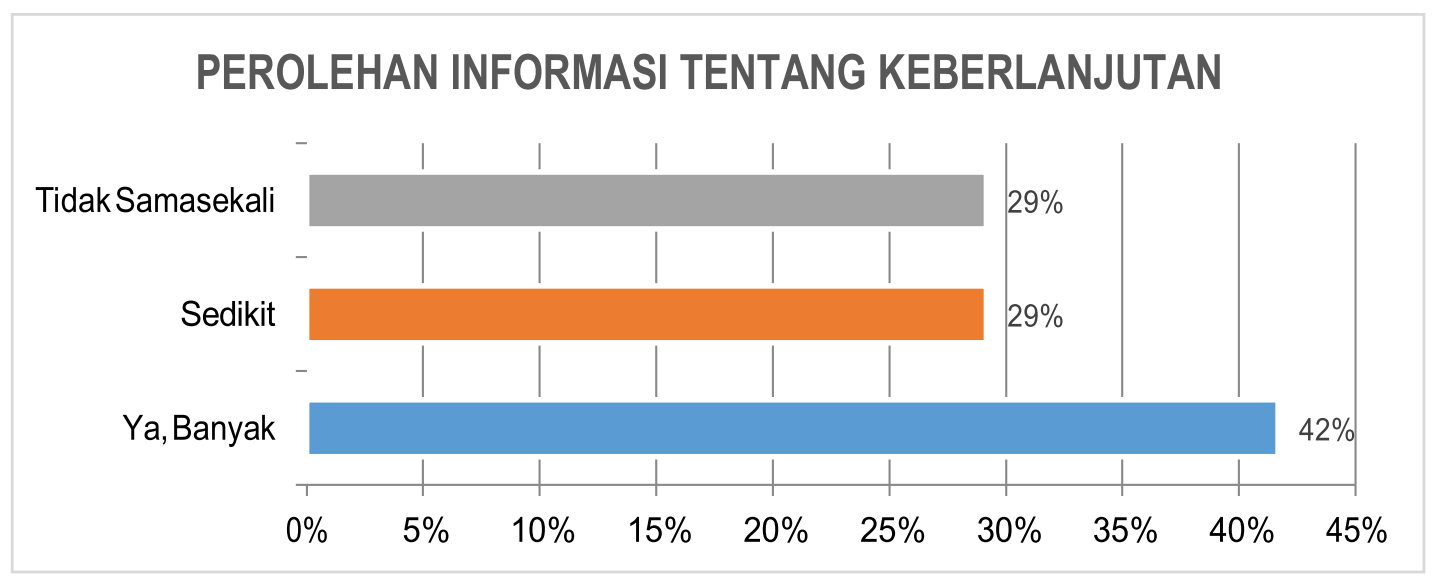

Gambar 19. Perolehan Informasi Tentang Keberlanjutan

\section{Sumber Informasi Tentang Keberlanjutan}

Sumber informasi yang diperoleh wisatawan berasal dari berbagai sumber. Wisatawan paling banyak mendapatkan informasi tentang pariwisata berkelanjutan dari internet sebanyak $26 \%$, sedangkan $20 \%$ dari Tour Operator, $18 \%$ dari tanda-tanda dalam area wisata, $14 \%$ berasal dari media cetak, $10 \%$ berasal dari Dive Operator dan otoritas Taman Nasional dan $2 \%$ berasal dari pemandu perjalanan.

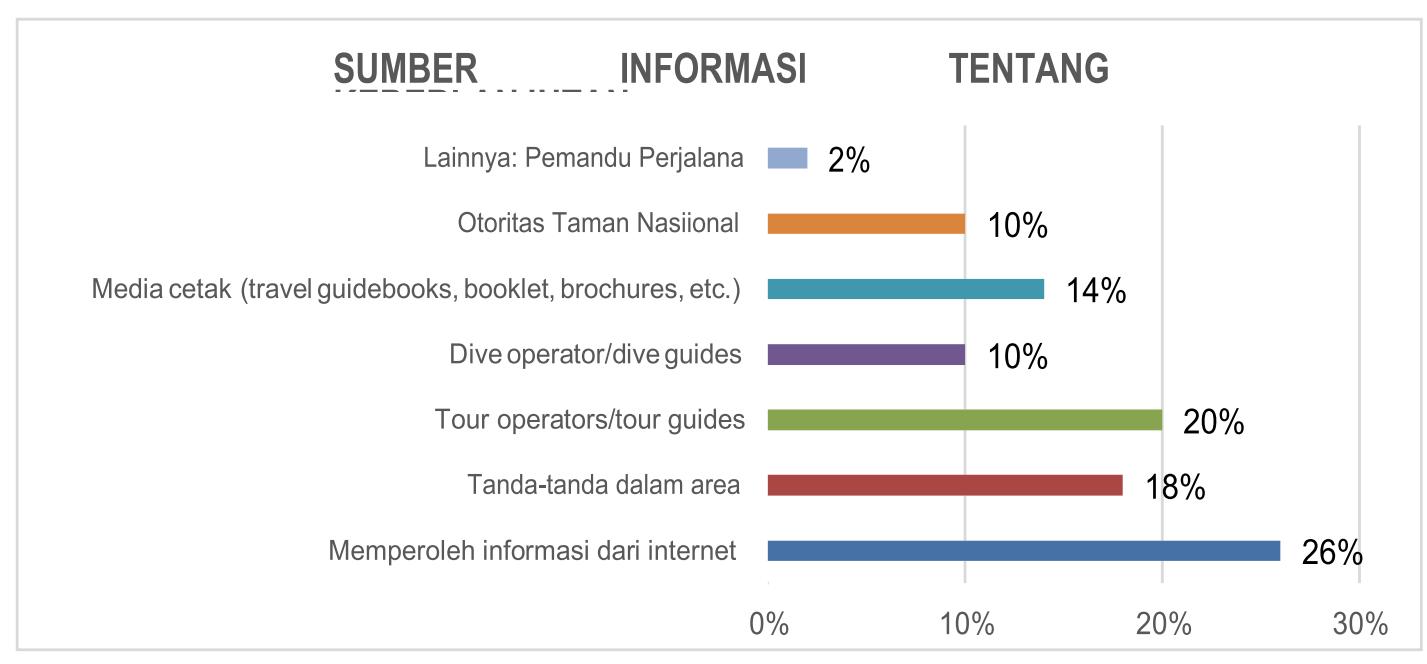


Gambar 20. Sumber Informasi Tentang Keberlanjutan

\section{G. Penginapan}

Dari hasil survey menunjukkan bahwa 58\% wisatawan memilih hotel sebagai tempat untuk menginap sedangkan 28\% memilih penginapan di Resort dan 14\% memilih tinggal di Homestay.

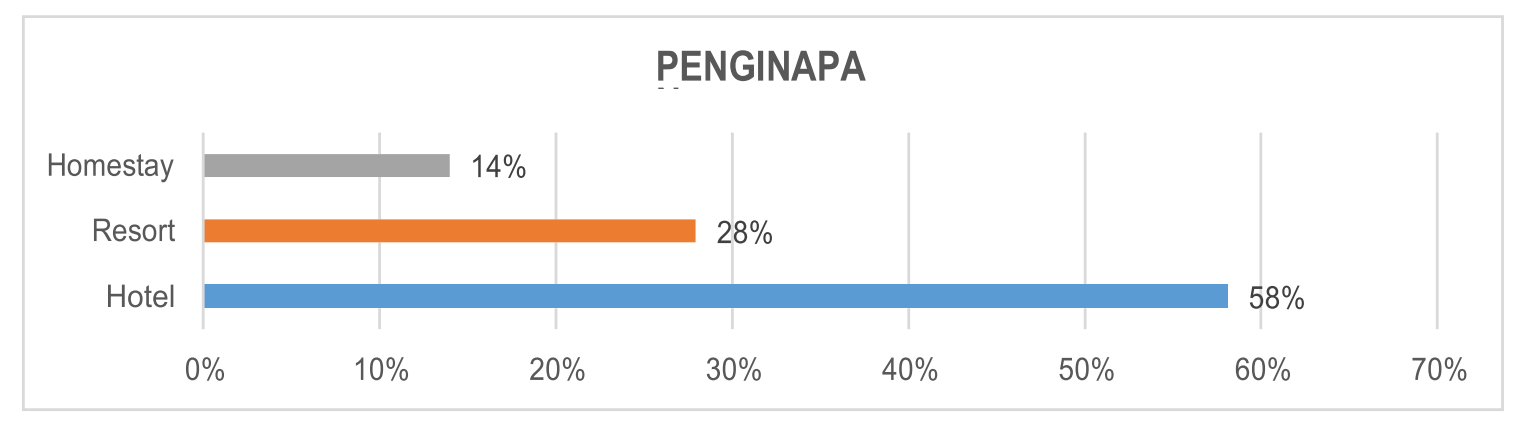

Gambar 21. Penginapan Wisatawan

\section{H. Kepuasan Terhadap Pelayanan Dan Fasilitas}

\section{Tingkat Kepuasan Wisatawan Terhadap Pelayanan dan Fasilitas di Masing- masing Destinasi}

Tingkat kepuasan wisatawan merupkan salah satu alat ukur yang dapat digunakan untuk memotret keberhasilan pengembangan sebuah destinasi. Analisis tingkat kepuasan wisatawan di Labuan Bajo diukur menggunakan alat analisis Tourist Satisfaction Index (TSI). Penentuan kriteria tingkat kepuasan dilakukan berdasarkan nilai CSI yang di peroleh. Nilai dan Kriteria Indeks Kepuasan Wisatawan sebagaimana tersaji di Tabel 2.1.

414 JUMPA Volume 6, Nomor 2, Januari 2020 
Tabel 1. Nilai dan Kriteria Tourist Satisfaction Index

\begin{tabular}{|c|c|c|}
\hline No & Nilai Index (100\%) & Kriteria \\
\hline 1. & $80 \%<$ satisfaction index $5100 \%$ & Sangat Puas \\
\hline 2. & $60 \%<$ satisfaction index $\leqq 80 \%$ & Puas \\
\hline 3. & $40 \%<$ satisfaction index $\leqq 60 \%$ & Cukup Puas \\
\hline 4. & $20 \%<$ satisfaction index $540 \%$ & Kurang Puas \\
\hline 5. & $0 \%<$ satisfaction index $\leqq 20 \%$ & Tidak Puas \\
\hline
\end{tabular}

Sumber Panduan Survei Kepuasan Konsumen PT. Sucoofindo dalam Kartikawati (2008)

Berdasarkan analisis data tersebut, maka diperoleh hasil tentang tingkat kepuasan penginjung terhadap fasilitas dan pelayanan di masing-masing destinasi sebagai berikut:

a. Tingkat kepuasan wisatawan terhadap fasilitas dan pelayanan yang ada di Batu Cermin berada pada nilai Indeks Kepuasan Wisatawan 76,45\%, artinya tingkat kepuasan wisatawan yang berkunjung ke Batu Cermin berada pada kriteria PUAS

b. Tingkat kepuasan wisatawan terhadap fasilitas dan pelayanan yang ada di Taman Nasional Komodo, berada pada nilai Indeks Kepuasan Wisatawan 75,65\%, artinya tingkat kepuasan wisatawan yang berkunjung ke Taman Nasional Komodo berada pada kriteria PUAS

c. Tingkat kepuasan wisatawan terhadap fasilitas dan pelayanan yang ada di Mello Village, berada pada nilai Indeks Kepuasan Wisatawan 75,65\%, artinya tingkat kepuasan wisatawan yang berkunjung ke Mello Village berada pada kriteria PUAS 
d. Tingkat kepuasan wisatawan terhadap fasilitas dan pelayanan yang ada di Goa Rangko berada pada nilai Indeks Kepuasan Wisatawan 69,99\%. Walaupun nilai indeks kepuasan berada di bawah 70\% namun kondiri ini masih termasuk dalam kriteria PUAS

e. Tingkat kepuasan wisatawan terhadap fasilitas dan pelayanan yang ada di Cunca Rami, berada pada nilai Indeks Kepuasan Wisatawan 69,47\%, artinya kepuasan wisatawan yang berkunjung ke Cunca Rami termasuk dalam kriteria PUAS

f. Tingkat kepuasan wisatawan terhadap fasilitas dan pelayanan yang ada di Liang Dara Village berada pada nilai Indeks Kepuasan Wisatawan 60,99\%, artinya tingkat kepuasan wisatawan yang berkunjung ke Batu Cermin termasuk dalam kriteria PUAS

g. Tingkat kepuasan wisatawan terhadap fasilitas dan pelayanan yang ada di Cunca Wulang berada pada nilai Indeks Kepuasan Wisatawan 60,65\%, artinya tingkat kepuasan wisatawan yang berkunjung ke Cunca Wulang masuk pada kriteria PUAS

h. Tingkat kepuasan wisatawan terhadap fasilitas dan pelayanan yang ada di Sano Nggoang berada pada nilai Indeks Kepuasan Wisatawan 55,28\%, artinya tingkat kepuasan wisatawan yang berkunjung ke Sano Nggoang termasuk dalam kriteria CUKUP PUAS. Sano Nggoang merupakan tempat wisata yang mendapat nilai indeks kepuasan wisatawan yang paling rendah karena fasilitas yang ada di destinasi ini sangat terbatas dengan pelayanan yang seadanya. 


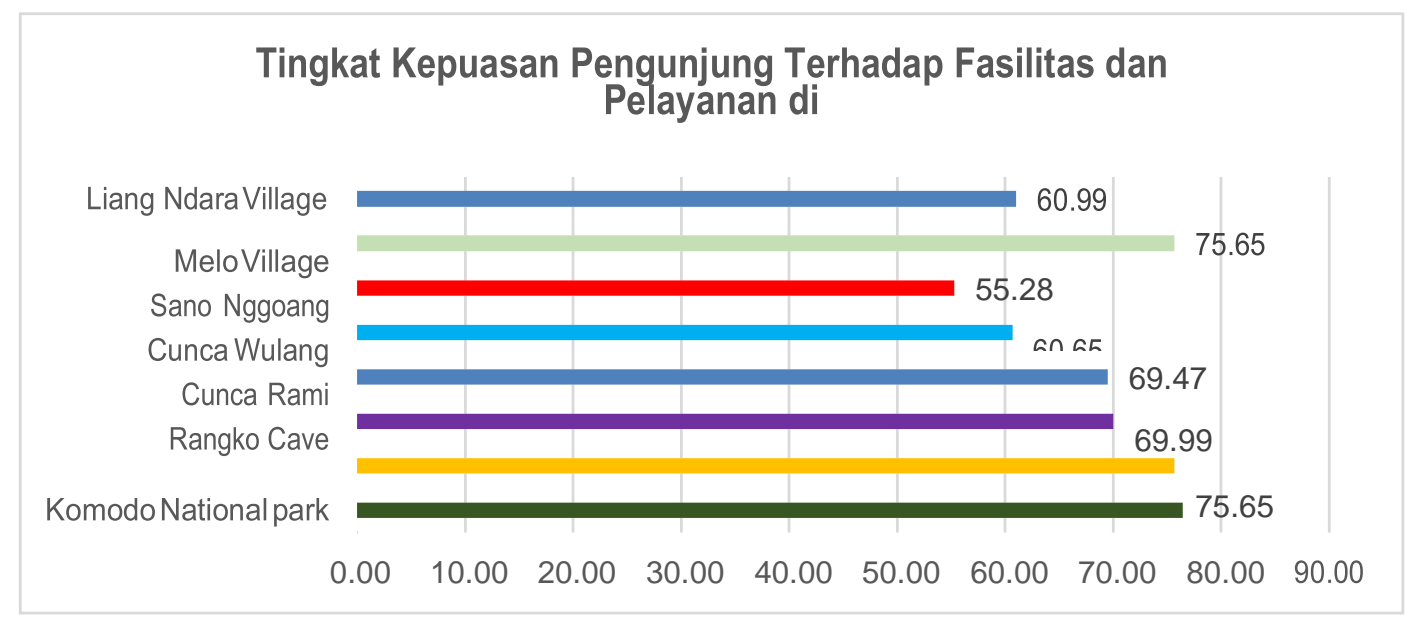

Gambar 22. Tingkat Kepuasan Pengunjung Terhadap Pelayanan dan Fasilitas

\section{Tingkat Kepuasan Wisatawan Terhadap Pelayanan dan Fasilitas Pendukung di Labuan Bajo}

Tingkat kepuasan wisatawan terhadap pelayanan dan fasilitas pendukung rata-rata berada pada kriteria PUAS. Hal ini ditunjukkan dengan nilai Indeks kepuasan untuk Bandara Komodo sebesar 77,10\%, Guides 72,73\%, Dive Operators 72,65\% serta Hotel \& Restoran 72,65\%. Hal ini menunjukkan bahwa ketersediaan fasilitas pendukung dan pelayanan fasilitas pendukung sudah baik, tetapi masih perlu peningkatan agar indeks kepuasan wisatawan dapat meningkat menjadi kriteria SANGAT PUAS.

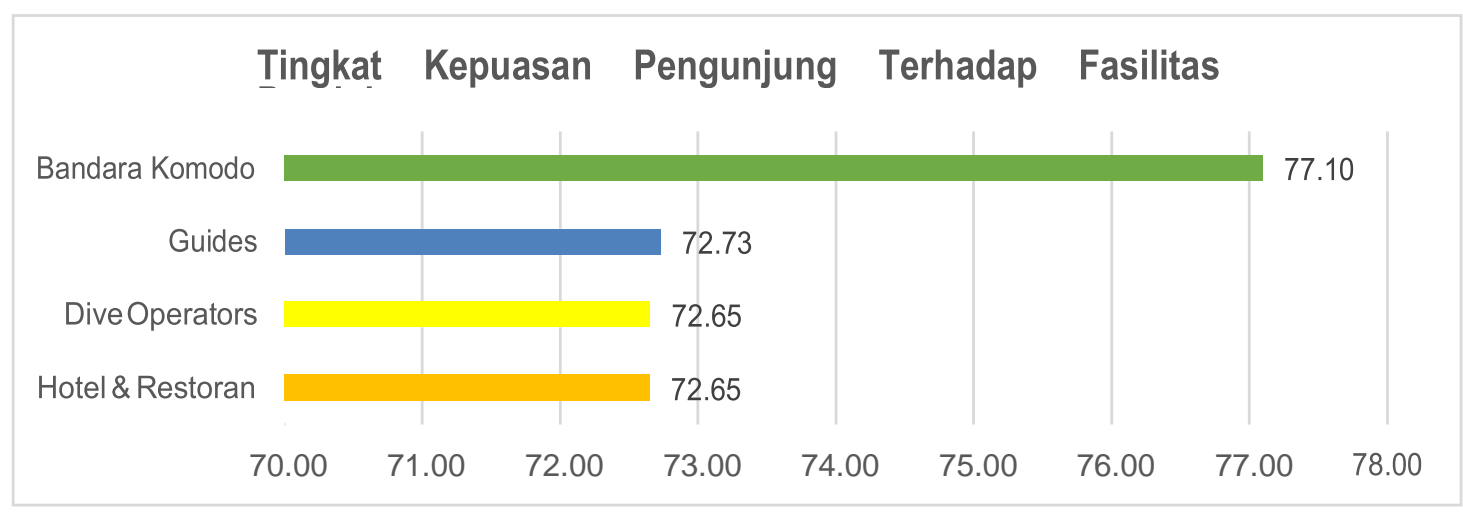

Gambar 23. Tingkat Kepuasan Wisatawan Terhadap Fasilitas Pendukung JUMPA Volume 6, Nomor 2, Januari 2020 


\section{Tingkat Kepuasan Wisatawan Terhadap AspekKeamanan, Budaya dan Lingkungan di Labuan Bajo}

Aspek keamanan dan keselamatan wisatawan memperoleh nilai indeks kepuasan sebesar 77,92\%, artinya tingkat kepuasan wisatawan dalam hal keamanan dan keselamatan di Labuan Bajo berada pada kategori PUAS.

\section{Tingkat Kepuasan Pengunjung Terhadap Aspek Keamanan, Budaya \&

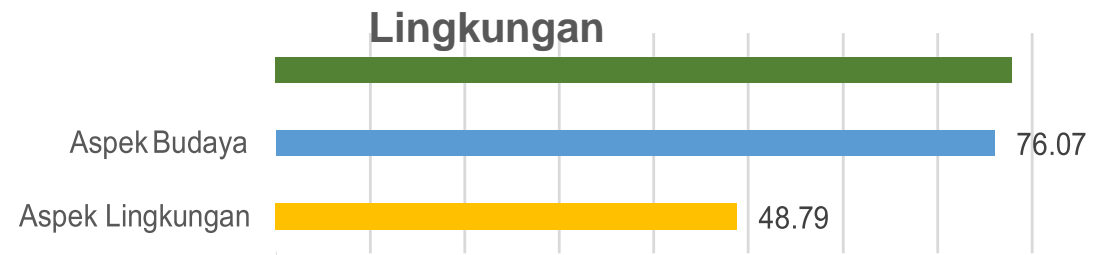 \\ 0.0010 .0020 .0030 .0040 .0050 .0060 .0070 .0080 .0090 .00}

Gambar 24. Tingkat Kepuasan Wisatawan Terhadap Aspek Pendukung Wisata

Aspek budaya berada pada kriteria PUAS dengan nilai indeks kepuasan sebesar $76,07 \%$. Seperti halnya aspek keamanan dan keselamatan, wisatawan merasa PUAS dengan suguhan aspek budaya yang ditawarkan kepada wistawan di Labuan Bajo. Berbeda dengan aspek keamanan dan keselamatan, aspek lingkungan memperoleh nilai indeks kepuasan pengunjung yang rendah yaitu 48,79\%. Ini berarti aspek lingkungan berada pada kriteria CUKUP PUAS. Dengan demikian dapat dikatakan bahwa lingkungan sekitar Labuan Bajo perlu mendapatkan pembenahan terutama yang berkaitan dengan sampah dan pengelolaannya.

\section{Pengalaman dan Rekomendasi}

\section{Pengalaman Menarik Wisatawan}

Kebanyakan dari wisatawan mengatakan pengalaman yang paling menarik saat berkunjung ke Labuan bajo adalah menikmati pemandangan yang indah (30\%) serta 418 JUMPA Volume 6, Nomor 2, Januari 2020 
dapat menjelajah ke pulau-pulau yang ada di Labuan Bajo (25\%). Sebanyak 9\% menyatakan pengalaman menariknya adalah snorkling, 7\% melihat komodo dan berenang dengan manta sedangkan 5\% menyatakan melihat pantai yang indah.

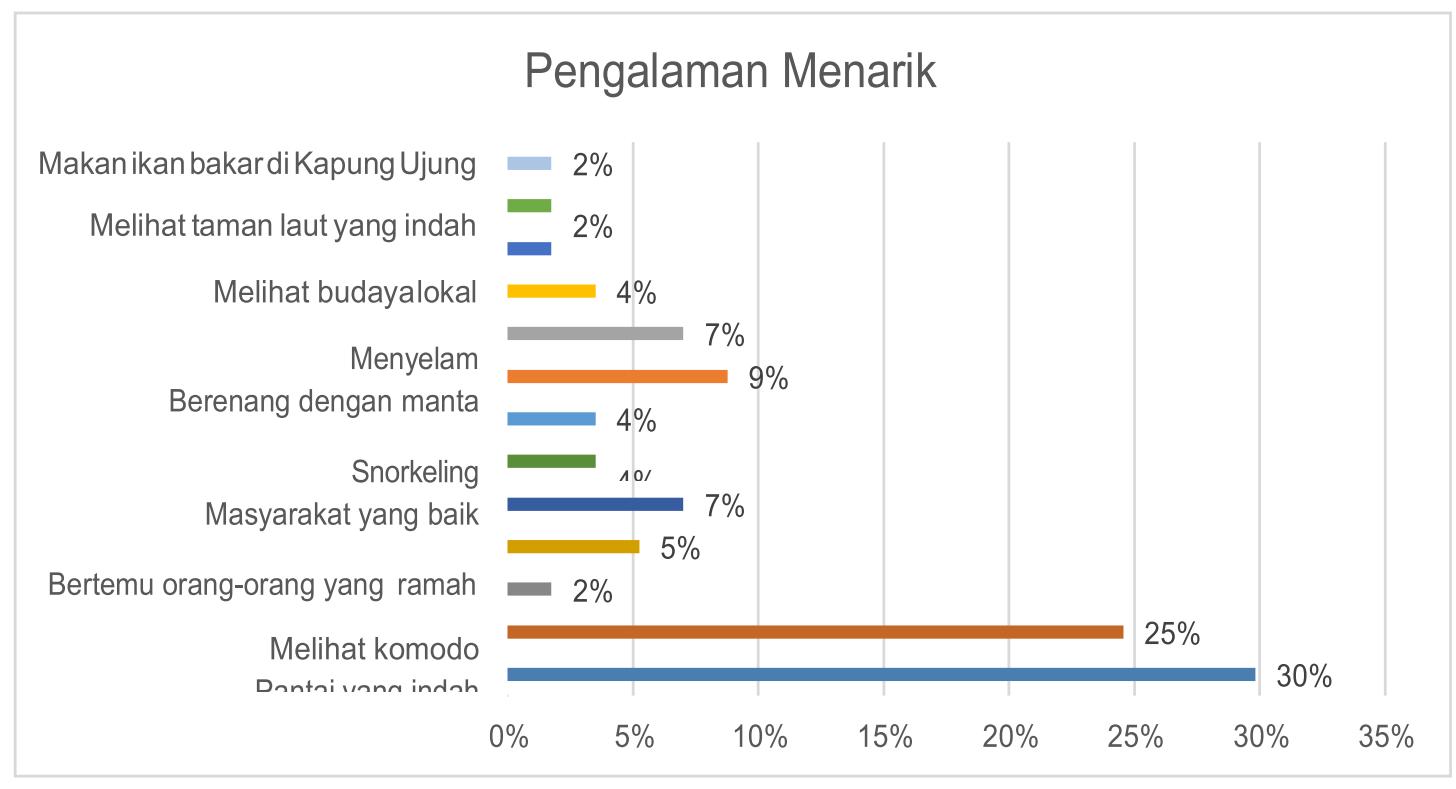

Gambar 25. Pengalaman Menarik Wisatawan

\section{Rekomendasi}

Rekomendasi yang paling banyak dari wisatawan adalah agar membangun kembali kota, menyediakan tempat sampah dan pengelolaan sampah yang lebih baik sebanyak 63\%), Labuan Bajo harus lebih bersih sebanyak 53\%, menyediakan angkutan umum sebanyak membuat kota lebih bersih lagi, menyadiakan angkutan umum serta memperluas area tracking dan snorkeling. 


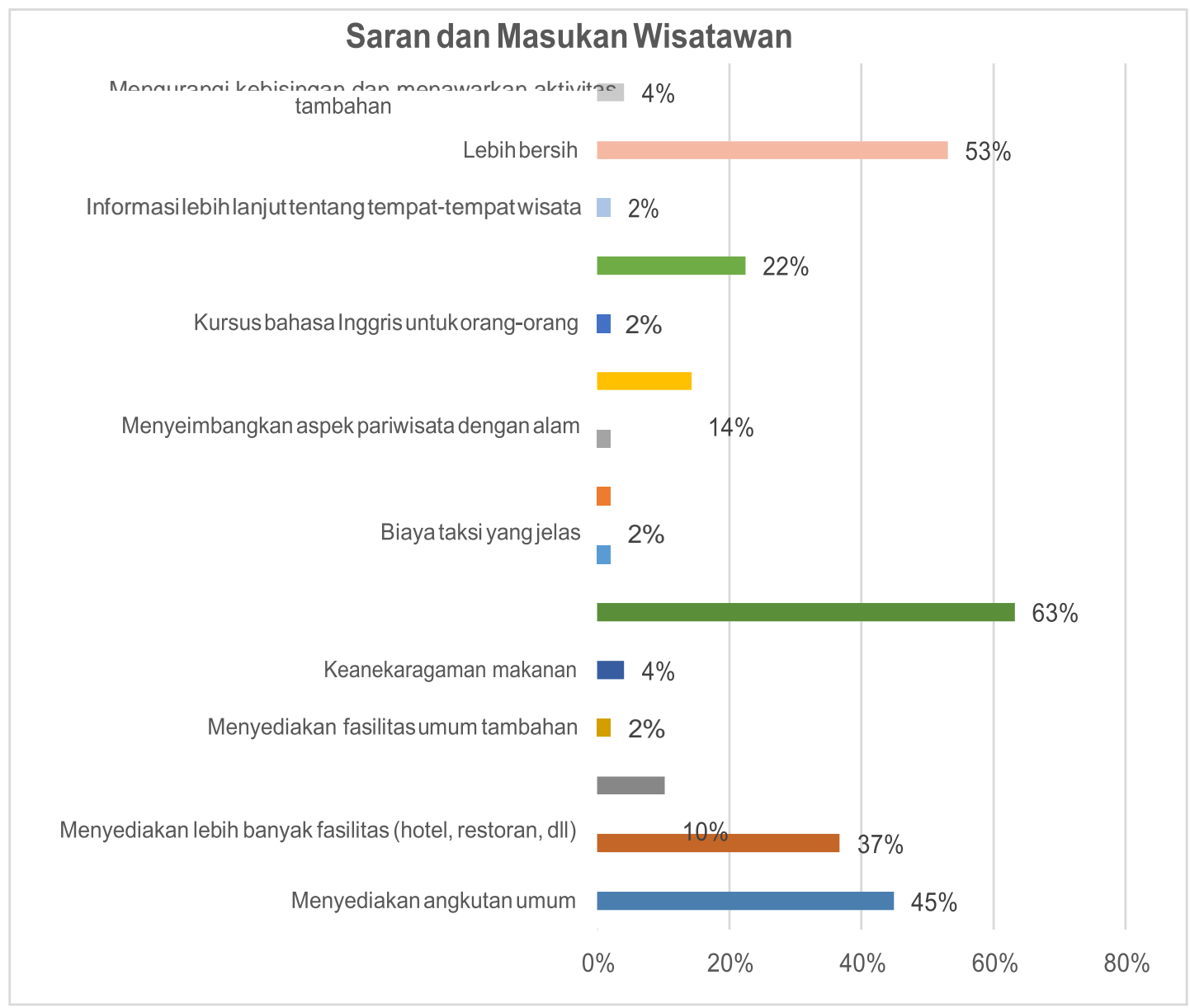

Gambar 26. Saran dan Masukan Wisatawan

\section{Kesimpulan dan Saran}

\section{Kesimpulan}

Berdasarkan hasil analisis exit survey terhadap kepuasan wisatawan di Labuan Bajo dapat disimpulkan beberapa hal sebagai berikut :

- Berdasarkan data profil responden, wisatawan terbanyak dari Manca Negara berasal dari Spanyol dan Malaysia selain wisatawan domestik 
- Rentang usia wisatawan yang paling banyak mengunjungi Labuan Bajo berkisar antara $23-47$ tahun

- Sumber perolehan infomrasi wisatawan yang paling banyak adalah dari teman atau anggota keluarga, media sosial, website dan trip advisor

- Kegiatan yang paling banyak dilakukan wisatawan di Labuan bajo adalah rekreasi, menikmati pantai dan pulau-pulau

- Rata-rata lama tinggal wisatawan di Labuan Bajo adalah 5,13 hari dengan frekuensi terbanyak adalah 3 hari

- Kunjungan yang dilakukan oleh wisatawan yang menjadi responden kebanyakan merupakan kunjungan pertama kalinya ke Labuan Bajo

- Jumlah wisatawan yang menjadilakn Labuan Bajo sebagai destinasi utama liburan cukup banyak walaupun tidak sampai 50\% dari total responden

- Sebagian besar wisatawan mengatur sendiri perjalanannya dan hanya sedikit yang menggunakan Tour Operator

- Total biaya yang dikeluarkan oleh wisatawan selama di Labuan Bajo berkisar antara US\$1,001 - 2,000 atau setara dengan Rp.15.000.000 - Rp. 30.000 .000

- Sebanyak $49 \%$ wisatawan menyatakan membeli souvenir dengan nominal berkisar antara Rp.750.000 - Rp.7.500.000

- Sebagian besar wisatawan paham tentang konsep keberlanjutan pariwisata dari internet dan tour operator dan tour guide

- Sebagian besar wisatawan menyatakan PUAS dengan kondisi fasilitas dan pelayanan di semua destinasi yang ada di Labuan Bajo kecuali Sano Nggoang yang termasuk dalam kategori CUKUP PUAS 
- Tingkat kepuasan wisatawan terhadap aspek keamanan dan keselamatan serta budaya berada dalam kategori memuaskan kecuali aspek lingkungan yang termasuk dalam kategori CUKUP PUAS

- Pengalaman paling menarik wisatawan selama mengunjungi Labuan Bajo adalah menikmati pemandangan alam yang indah dan menjelajah ke pulau-pulau

\section{Saran}

Rekomendasi yang paling banyak disampaikan oleh wisatawan terhadap pariwisata Labuan bajo adalah yang berkaitan dengan kebersihan lingkungan terutama menyangkut pengelolaan sampah di dalam kota dan tempat-tempat wisata. Urutan saran dan rekomendasi dari wisatawan sebagai berikut :

- Membangun Kota Labuan Bajo dengan penataan lebih baik

- Meningkatkan jumlah tempat sampah dan pengelolaannya

- Meningkatkan kebersihan obyek wisata dan sekitarnya

- Menyediakan angkutan umum

- Memperluas area untuk tracking dan snorkling

- Meningkatkan sistem perlindungan di laut dan di alam bagi wisatawan

- Menyeimbangkan aspek pariwisata dengan alam

- Menyediakan lebih banyak fasilitas wisata seperti hotel, restoran dan pusat informasi pariwisata 


\section{Ucapan Terima Kasih}

Penulis mengucapkan terima kasih kepada Rektor Universitas Flores yang telah memberikan kesempatan berada di Pusat Studi Pariwisata Universitas Flores dan kepada Ketua Pusat Studi Pariwisata yang telah memberikan kesempatan untuk bergabung menjadi anggota MCSTO Universitas Flores dengan wilayah dampingan Labuan Bajo., kepada Kementrian Pariwisata Republik Indonesia sebagai penyandang dana penelitian ini., kepada Kepala Dinas Pariwisata Manggarai Barat bersama staf yang telah memberikan banyak bantuan., kepada TIM MCSTO yang telah bekerja dengan sangat giat untuk mengumpulkan data, seluruh narasumber serta semua pihak yang telah membantu penulis dalam melakukan penelitian ini.

\section{Daftar Pustaka}

Dinas Pariwisata, Kabupaten Manggarai barat, S. P. (2018) ‘Laporan Exit survey / Survey Kepuasan Pengunjung Flores Barat'.

Hill, B. N., Roche, G. and Allen, R. (2007) 'Customer Satisfaction: The customer experience through the customer's eyes', (November), p. 2007.

Kotler, P. (2009) Marketing Management Millenium Edition, Tenth Edition. PrenticeHall, Inc.

Modestus Ziku, R. (2015) 'Partisipasi Masyarakat Desa Komodo Dalam Pengembangan Ekowisata Di Pulau Komodo', Jurnal Master Pariwisata (JUMPA), 2, pp. 1-21. doi: 10.24843/jumpa.2015.v02.i01.p01.

Murianto, M. (2014) ‘Potensi Dan Persepsi Masyarakat Serta Wisatawan Terhadap Pengembangan Ekowisata Di Desa Aik Berik, Lombok Tengah', Jurnal Master Pariwisata (JUMPA), 01, pp. 43-64. doi: 10.24843/jumpa.2014.v01.i01.p03.

Utama, I. G. B. R. (2016) 'Teknik Sampling dan Penentuan Jumlah sampel', Universitas Dhyana Pura, Bali, (January), p. 23. doi: 10.13140/RG.2.1.5187.0808.

Oliver, Richard L. (2015). Satisfaction, A Behavioral Perspective on The Consumer, New York: Routledge.

Soekadijo, R,G. 2000, Anatomi Pariwisata. Jakarta : Gramedia Pustaka Utama 
Rekomendasi Tindak Lanjut Seminar Problematik Tanah Duwe Desa Pakraman "Identifikasi, Solusi, dan Strategi, pada Jumat, 18 Juni 2004 di Hotel INNA Sindhu Beach, Sanur.

Moleong, Lexy J, 1998, Metode Penelitian Kualitatif, Bandung: Remaja Rusdakarya

Nasikun, DR, Model Pariwisata Pedesaan: pemodelan pariwisata pedesaan untuk Pembangunan Pedesaan yang Berkelanjutan.1997.ITB

Bukart and Medlik. 1976. Tourism. London. Cox and Wyman Ltd.

\section{Profil Penulis}

Apriana Marselina, SE., M.Sc adalah Dosen Program Studi Akuntansi Fakultas Ekonomi Universitas Flores, dan menjabat sebagai Bendahara MCSTO Universitas Flores.

Dr. Ernesta Leha, SE., M.Agb adalah Dosen Program Studi Ekonomi Pembangunan Fakultas Ekonomi Universits Flores dan menjabat sebagai Ketua Pusat Studi Pariwisata Universitas Flores dan Ketua MCSTO Universitas Flores wilayah dampingan Labuan Bajo.

Maria Kristina Ota, S.Pd., M.Pd adalah Dosen Pendidikan Guru Sekolah Dasar Fakultas Keguruan dan Ilmu Pendidikan Universitas Flores. 